Article

\title{
International Investment Agreements Provisions and Foreign Direct Investment Flows in the Regional Comprehensive Economic Partnership Region
}

\author{
Nathapornpan Piyaareekul Uttama
}

Citation: Uttama, Nathapornpan Piyaareekul. 2021. International Investment Agreements Provisions and Foreign Direct Investment Flows in the Regional Comprehensive Economic Partnership Region. Economies 9: 28. https://doi.org/ 10.3390/economies 9010028

Academic Editor: Ralf Fendel

Received: 8 January 2021

Accepted: 20 February 2021

Published: 2 March 2021

Publisher's Note: MDPI stays neutral with regard to jurisdictional claims in published maps and institutional affiliations.

Copyright: (C) 2021 by the author. Licensee MDPI, Basel, Switzerland. This article is an open access article distributed under the terms and conditions of the Creative Commons Attribution (CC BY) license (https:// creativecommons.org/licenses/by/ $4.0 /)$.
School of Management, Mae Fah Luang University, Chiang Rai 57100, Thailand; nathapornpan@mfu.ac.th

\begin{abstract}
The international investment agreements (IIAs) are a strategic policy instrument that member countries could use to achieve win-win cooperation. Meanwhile, the extension of the Association of Southeast Asian Nations (ASEAN) membership toward the Regional Comprehensive Economic Partnership (RCEP) membership has induced the rich and deep investment agreement that challenges the ASEAN countries to take advantage. This study demonstrates the effects of investment provisions in international investment agreements on the bilateral foreign direct investment (FDI) in the RCEP economies. It also investigates the effect of ASEAN membership on investment creation and investment diversion toward the RCEP region. Using panel data on RCEP countries during the period 2009 to 2018 and a Driscoll-Kraay standard errors estimator, the results show that the re-lationship between inward FDI and investment provisions in IIAs are positive and significant. Likewise, the investment protection, and promotion provisions in bilateral investment treaties have positive and significant effects on the inward FDI. Moreover, the findings indicate that the ASEAN membership tends to cause the investment creation toward the RCEP region; and it is a stepping stone on the road to the investment policy framework for sustainable development.
\end{abstract}

Keywords: international investment agreement; foreign direct investment; investment creation and diversion; Association of Southeast Asian Nations; regional comprehensive economic partnership

\section{Introduction}

The International investment agreements are an important instrument driving foreign investment activities. As of December 2020, more than 2600 international investment agreements were in force, with 2342 bilateral investment treaties (BITs) and 322 treaties with investment provision (TIPs) (UNCTAD 2020b). Figure 1 shows the total current number of IIAs signed and in force in the Regional Comprehensive Economic Partnership region being the world's biggest regional economic agreement. Countries with the highest number of IIAs were China, followed by South Korea, Malaysia, Singapore, Vietnam, and Thailand. The average inward FDI and outward FDI as percentages of GDP in the RCEP in 2019 were approximately 71\% and 35\%, respectively (Figure 2). Singapore was the largest recipient of FDI inflows in the RCEP region, with approximately 469\% of GDP. Simultaneously, Singapore, Australia, and Japan were the largest investors of FDI in the RCEP region, with approximately 306\%, 41\%, and 36\% of GDP, respectively. Japan, South Korea, and China tended to be investing countries rather than recipient countries of FDI, with a larger outward FDI than an inward FDI. Countries with inward FDI oriented were Brunei, Cambodia, Lao PDR, Myanmar, and Vietnam that Cambodia had the highest FDI dependency among all these countries. As mentioned, the significance of IIAs and FDI inflow in the RCEP was quite clear, but however, the relationship between the IIAs and FDI activities in the RCEP could be inconclusive. 


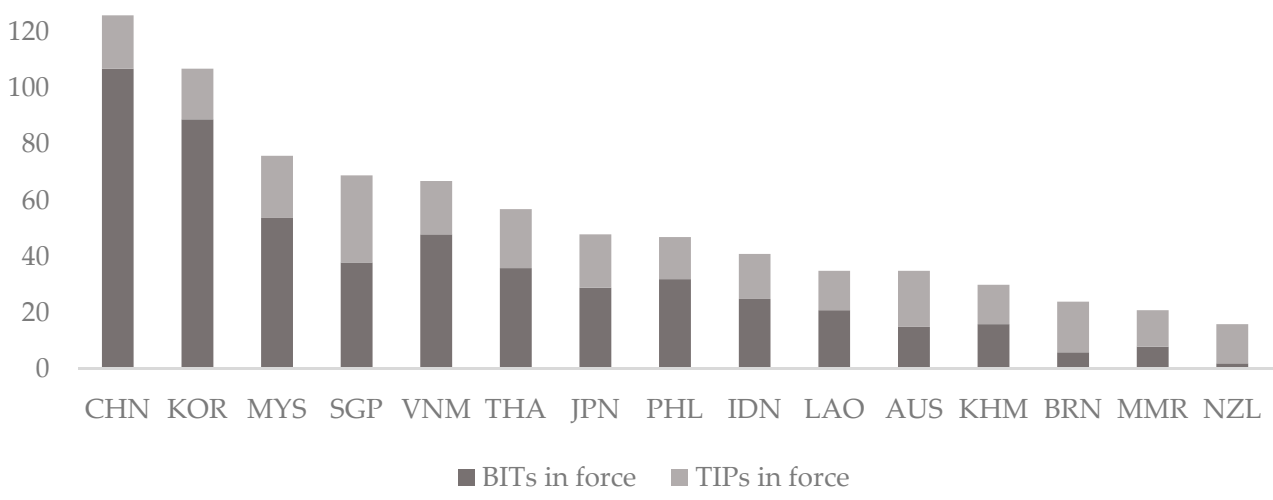

Figure 1. The cumulative number of BITs and TIPs in the RCEP, 2020. Source: Author's compilation using data from UNCTAD (2020b).

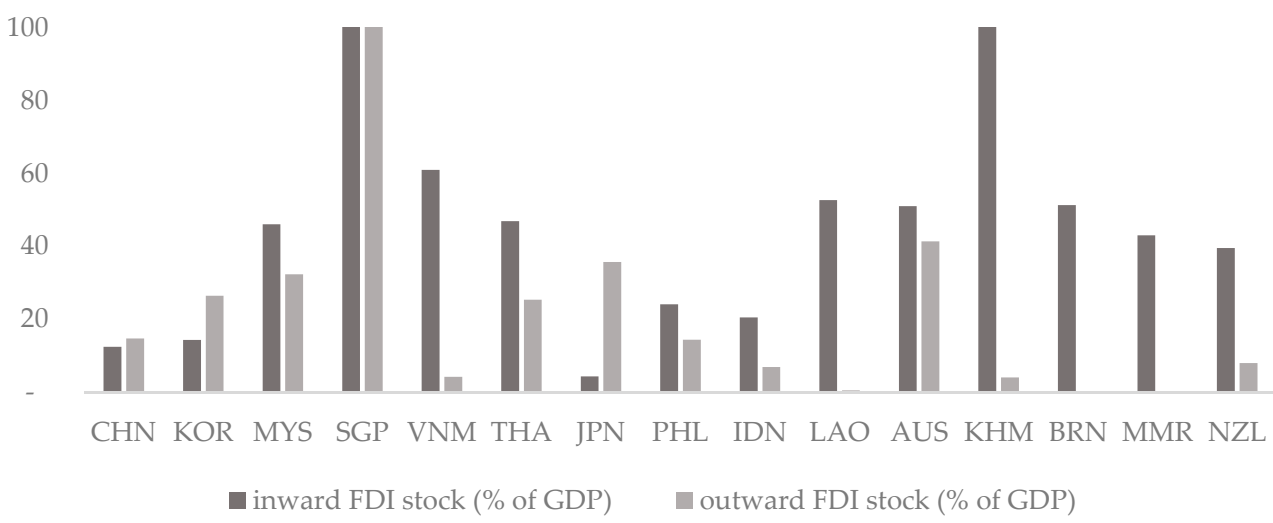

Figure 2. The FDI stock as a percentage of GDP in the RCEP region, 2019. Source: Author's compilation using data from UNCTAD (2020c).

The issue of international investment agreement provisions has gained momentum over the last decade. Recently, the UNCTAD designed an investment policy framework for sustainable development (UNCTAD 2020a), aiming to attract and benefit from the investment. As international investment agreements come under fire from foreign economic policy, it becomes ever more important to investigate the effects of investment agreements on FDI and their membership on the investment effects. In particular, the membership of the RCEP agreement is important to stimulate intra-bloc FDI activities. Regarding the existing studies on the consequences of IIAs, although many of them investigated how IIAs were associated with the inward and outward FDI (Aisbett et al. 2018; Bengoa et al. 2020; Berger et al. 2013; Dixon and Haslam 2015; Egger and Merlo 2012; Jung and Kim 2019; Neumayer et al. 2016; Zeng and Lu 2016), few studies have discussed the relationship between various investment provisions (investment protection, facilitation, and promotion) of IIAs and FDI activities. Meanwhile, the relationship between IIAs and FDI in the RCEP remains questionable due to the lack of conclusive theoretical discussion and empirical results. These arguments encourage us to conduct a piece of empirical evidence with two research questions: (i) Are FDI flows in the RCEP region susceptible to investment provisions in IIAs? and (ii) Would the membership of ASEAN cause the investment creation and diversion?

Accordingly, this study concentrates on addressing the effect of investment provisions in international investment agreements on the foreign direct investment in the RCEP countries over the period 2009-2018 using a regression model with a Driscoll-Kraay standard errors approach. We start with the question of whether foreign direct investment is sensitive to investment provisions in IIAs. The results suggest that the investment provisions in IIAs have a positive and significant effect on inward FDI, and the FDI activities on the ASEAN 
membership cause the investment creation toward the RCEP countries. It also implies that the extension of the ASEAN agreement to the RCEP agreement becomes a stepping stone on the road to the investment policy framework for sustainable development.

Our contribution to the literature of the effect of IIAs on FDI is different from the existing studies with an emphasis on (i) diversified investment provisions in IIAs such as the provisions on investment protection, investment facilitation, and investment promotion, (ii) different schemes of foreign direct investment by using a panel dataset containing 16 RCEP countries between 2009-2018, and (iii) different regionalisms on investment creation and diversion.

The remainder of this paper is organized as follows. Section 2 reviews the literature related to international investment agreements on foreign direct investment. Section 3 addresses the estimation model and data collection. Section 4 presents and discusses the empirical results. Section 5 concludes.

\section{Theoretical Framework}

This section describes the review into two aspects: (i) the effects of international investment agreements on foreign direct investment and (ii) the effect of membership in IIAs causing the investment creation and diversion. The following literature review is used to formulate the hypotheses in this study.

\subsection{Effect of International Investment Agreement on Foreign Direct Investment}

To date, there is much debate and literature regarding the effect of the presence of international investment agreements on foreign direct investment. Meanwhile, there is limited literature on the effect of IIA provisions on bilateral FDI. In light of the presence of IIAs more recent studies have focused on the relationship between the number of bilateral investment treaties and treaties with investment provisions and foreign direct investment. These studies usually suggested their strong relationship as rigorous as possible (Colen et al. 2016; Desbordes and Vicard 2009; Medvedev 2012; Nguyen et al. 2020; Wang 2016). Moreover, Desbordes and Vicard (2009) indicated that the BITs with the quality of political relation between signatory countries had a positive and significant effect on bilateral foreign direct investment. Colen et al. (2016) also suggested that the BITs for the real estate and utility sector had positive and significant impacts on FDI in Central and Eastern Europe and the Former Soviet Union. However, a recent work of Nguyen et al. (2020) found that the empirical evidence of the impact of BITs on FDI in Asian countries was ambiguous. The BITs provided a chance to encourage and/or to discourage FDI. Specifically, the argument that the related-investment provisions in regional economic integration caused a change in foreign direct investment flow to member countries has been conducted in empirical studies by Medvedev (2012) and Wang (2016), among others. Medvedev (2012) showed that the preferential trade arrangements had a positively significant impact on FDI inflows of participating countries. Similarly, the mainland and Hong Kong closer economic partnership arrangement had a positive effect on attracting FDI from Hong Kong to the mainland of China (Wang 2016).

Some literature points to the explanation of FDI flow associated with the signing and ratifying of IIAs and the investment provisions in IIAs (Aisbett et al. 2018; Beebeejaun 2018; Bengoa et al. 2020; Dixon and Haslam 2015; Egger and Merlo 2007; Egger and Merlo 2012; Egger and Pfaffermayr 2004; Frenkel and Walter 2018; Jacobs and Ostergard 2019; Jung and Kim 2019; Neumayer et al. 2016; Tulayasathien and Tejapaibul 2017; Xiao 2011; Zeng and Lu 2016). The first strand of reasoning makes the case that the signing and ratifying IIAs are used to attract foreign direct investment. Egger and Pfaffermayr (2004) examined the impacts of the signing and ratifying BITs of OECD investing countries on their outward foreign direct investment. They revealed that only the ratifying BITs had a positive and significant impact on outward FDI. The findings of Egger and Merlo (2007) regarding the short-run effect are also relevant. Moreover, they suggested that there was a positive and significant impact of ratifying BITs on outward FDI in the long-run. Conversely, 
Egger and Merlo (2012) investigated the impact of bilateral investment treaties on German multinational activity at the firm level. Their findings confirmed that the signing BITs had a positive and significant impact on the number of multinational firms, and the number of plants per firm in German, whereas the ratifying BITs had a positive and significant impact on various multi-national activities in German i.e., the number of multinational firms, FDI stock, fixed assets per firm, and a number of plants per firm. The signing and ratifying IIAs might be regarded as being more effective for FDI flow than multilateral or bilateral agreements that focused solely on the negotiation issue. Simultaneously, Jung and Kim (2019) revisited the impact of South Korea's BITs signed and enforced on its outward FDI flows and showed that both BITs signed and enforced had positive and significant effects on outward FDI.

The second explanation is that the investment provisions in IIAs are critical for attracting foreign direct investment. The core provisions in IIAs include provisions on investment liberalization, investment protection, investment facilitation, and investment promotion, in general (See Appendix A). There is an attempt to measure the degree of legal provisions of BITs for assessing the quality of BITs, so-called the 'BITSEL' index (Chaisse and Bellak 2011). Some studies show that investment provisions in IIAs can affect foreign direct investment. Dixon and Haslam (2015) studied the effect of the quality of investment protection in IIAs on foreign investment flow to Latin American countries. In this work, the quality of investment protection was measured on the variation in the textual content of IIAs into three levels: 'strong', 'medium', and 'weak' treaties. Their empirical results revealed that stronger investment provisions in IIAs had positive and significant impacts on FDI flow, whereas medium and weak IIAs had insignificant impacts on FDI.

Later, Berger et al. (2013) used the gravity model to investigate the relationship between the diversity of investment provisions in BITs and regional trade arrangement (RTAs) and bilateral FDI flow to developing recipient countries. Their empirical results confirmed that the liberal national treatment and strong investor-state dispute settlement provisions in RTAs and BITs had positive and significant impacts on bilateral FDI flows. Their findings are also consistent with Neumayer et al. (2016). The stricter FDI-related provisions related to investor-state dispute settlement and pre-establishment national treatment of foreign investors had positive and significant effects on FDI competition-driven contagion in developing recipient countries. Likewise, Zeng and Lu (2016) focused on the impacts of the BITs signed, the BITs enforced, and the stronger investment protection provisions on foreign direct investment flow to China. They defined three BITs' investment protection variables, i.e., absolute standard treatment, relative standard treatment, and dispute settlement procedure that captured the strength of investment protection provisions. Their empirical results indicated that the BITs enforced had a positive and significant impact on FDI, and there were positive and significant impacts of the stronger investment protection provisions on FDI flow. Aisbett et al. (2018) further discussed the investor-state dispute settlement provisions in BITs and BIT-related claims for compensation that could affect FDI flow to developing recipient countries. They found that BITs in force had a positive and significant impact on FDI flow to developing countries whenever there is no BIT claim against the host country.

Similarly, Frenkel and Walter (2018) built the individual 'BIT' scores of the BITs that explained the strength of international dispute settlement provision in all BITs that a country has signed. They hypothesized that higher BIT scores could raise FDI inflows, and their empirical results confirmed their hypothesis, i.e., stronger international dispute settlement provisions in BITs tended to attract foreign investment flow to recipient countries. A recent review of the literature (Bengoa et al. 2020) addressed the BIT investment protection index capturing the variations in the degree of investment protection across individual BITs in the Latin American region. They also examined their relationship with intra-regional FDI by using a structural gravity model. Their findings showed that the level of investment protection in BITs had a positive and significant effect on intra-regional FDI; and BITs 
interacted with regional trade arrangements i.e., the Mercosur region were more effective than individual BIT in attracting intra-regional FDI.

The third potential driver for the inclusion of investment provisions in IIAs is motivated by FDI consideration. Jacobs and Ostergard (2019) indicated that the existing empirical results on the effect of bilateral investment treaties on foreign direct investment were inconsistent due to the lack of consideration in variation within treaties. They suggested that treaty variation or treaty strength was important to change foreign direct investment, especially BITs across countries. They also proposed the measurement of BIT strength by scaling the exceptions, transfers, treatment, and broad treatment of BITs. The higher strength scores entailed higher investment protection for foreign investors that attracted foreign direct investment more generally. Xiao (2011) suggested that the ASEAN-China investment agreement with the investment liberalization, facilitation, and protection provisions gained benefits for member countries. Especially this agreement provided a higher standard of investment protection and investment liberalization rather than the bilateral investment treaties between China and individual ASEAN members and treaties with investment provisions in other regional trade agreements. The findings of Beebeejaun (2018) are also relevant. He confirmed that various IIAs in Mauritius such as bilateral trade agreements, investment promotion and protection agreements, double taxation agreements, and regional trade agreements were likely to attract FDI flows. Likewise, the ASEAN Comprehensive Investment Agreement (ACIA) framework developed from the ASEAN Investment Area, and Investment Guarantee Agreement treaties has covered investment liberalization, protection, facilitation, and promotion. This agreement provided the most advantageous benefits for foreign investors to cherry-pick an investment location (Tulayasathien and Tejapaibul 2017). Several aforementioned studies suggested that stronger investment protection provisions tend to increase FDI flow and multinational activities.

In summary, these studies usually focused on the effects of international investment agreements and their provisions on bilateral foreign direct investment. However, their findings remain largely unclear. Most findings indicated that IIAs and IIA's provisions rendered an increase in FDI.

Hypothesis 1 (H1). International investment agreements i.e., bilateral investment treaties and treaties with investment provisions are likely to increase inward foreign direct investment.

Hypothesis 2 (H2). Investment provisions (Investment protection, investment promotion, and investment facilitation) in international investment agreements tend to support an increase in bilateral foreign direct investment.

\subsection{Regionalism versus Investment Creation and Diversion}

While it is important to examine the effect of international investment agreement provisions on FDI, regional economic integration might have an effect on FDI in terms of investment creation and diversion. Investment creation is an increased FDI within member countries. Investment diversion, on the other hand, occurs when FDI flow from non-member countries to member countries tends to decrease and is replaced by member countries. With regard to the theoretical studies on investment creation and diversion, the most relevant literature is Konan and Heinrich (1997) and Baldwin et al. (2010) who studied the investment creation and investment diversion effects of preferential trade arrangements in member countries. They used the general equilibrium model to analyze those effects. Konan and Heinrich (1997) extended the 1994 Markusen and Venables multinational model and indicated that the level of external tariff in regional integration agreement caused a magnification effect on investment creation and diversion. The higher the external tariff rate, the greater the 'tariff-jumping' FDI in the member region was. Meanwhile, the higher the external tariff rate, the lower the 'tariff-jumping' FDI from non-members was. Baldwin et al. (2010) developed the general equilibrium model and suggested that larger regional 
integration tended to increase capital stock in member region (investment creation) and decrease it from the rest of the world (investment diversion). Moreover, their empirical results revealed that European integration rendered an increase in capital stock in the EU12 members and a decrease in capital stock in the EFTA6 members. The findings of Baldwin et al. (1996) are also relevant.

In the empirical literature, the preferential/regional trade agreements are expected to increase investment creation and decrease investment diversion (Dee and Gali 2005; Kreinin and Plummer 2008; Lakatos and Walmsley 2012; Park and Park 2009). Dee and Gali (2005) examined the effect of nontrade (e.g., foreign investment) provisions of preferential trading agreements (PTAs) on inward foreign direct investment. They revealed that there was no significant effect on intra-bloc investment in various PTAs, except for the North American free trade agreement that tended to reduce inward investment among members and raise inward investment from non-members (investment creation). Their findings also confirmed that the Andean pact and European free trade area caused a decrease in inward foreign investment from non-members (investment diversion).

Kreinin and Plummer (2008) employed the gravity model to investigate the effect of regional integration such as ASEAN on FDI flows. Their empirical results showed that regional integration had a positive and significant effect on Japan's FDI, implying the presence of investment creation in ASEAN. Likewise, Park and Park (2009) applied the gravity model to examine the investment creation and diversion effects of regional trade agreements (RTAs) in East Asia. Their findings indicated that the RTA membership had a positive and significant impact on inward FDI and it caused investment creation and no investment diversion. Lakatos and Walmsley (2012) refined the global computable general equilibrium (GTAP) model through bilateral ownership of an investment to simulate the investment creation and diversion effects of the ASEAN-China free trade agreement (ACFTA). They found clear evidence of investment creation effects of ACFTA in member countries and investment diversion effects in non-member regions.

The investment creation and diversion effects of the membership of international economic agreements have received relatively little empirical attention. For instance, Tanaka and Arita (2016) investigated a relationship between regional investment liberalization and FDI activity among participating countries. They found that regional investment liberalization caused investment creation with an increase in the entry of foreign firms in integrating countries, whereas it caused investment diversion with a slight decrease in multinational activities in non-integrating countries. Likewise, Bengoa et al. (2020) studied the effects of FDI creation and diversion of two regional trade arrangements, i.e., the Southern Common Market (Mercosur) and the Latin America Integration Association (ALADI). Their findings indicated that the formation of Mercosur and ALADI tended to take place an investment creation in members, whereas only Mercosur caused an investment diversion against non-members.

Hypothesis 3 (H3). Membership of international economic agreements causes investment creation and/or investment diversion in recipient countries of foreign direct investment.

As yet, there are no publications that have empirically investigated the effects of investment provisions in bilateral investment treaties and treaties with investment provisions on foreign direct investment flows in the Regional Comprehensive Economic Partnership region. The ASEAN Comprehensive Investment Agreement is one of the significant treaties because it coexists with ASEAN's bilateral investment treaties and treaties with investment provisions altogether which might be a percussion of investment integration in Southeast Asia. Meanwhile, the RCEP region is expected to be a large single market and production base envisioned in the world. This gives a distinct motivation for studying this paper. 


\section{Economic Approach}

\subsection{Model}

To examine the relationship between international investment agreement provisions and bilateral foreign direct investment, we build the empirical model based on the knowledge-capital model of FDI (Markusen 2002) and the BITs-driven-FDI model of Egger and Pfaffermayr (2004). The knowledge-capital model of FDI has been extensively used to examine how FDI flows and multinational activities are influenced by economic size, the relative difference in factor endowments, and trade costs. The Egger and Pfaffermayr (2004) model incorporated bilateral investment agreements into the knowledge-capital model and empirically investigated it. They found a positive and significant relationship between the ratifying BITs and FDI. Therefore, our empirical specification is defined as the following model:

$$
\begin{aligned}
& \ln \left(f d i_{i j t}\right)=\beta_{0}+\beta_{1} \ln \left(s g d p_{i j t}\right)+\beta_{2} \ln \left(\operatorname{sim}_{i j t}\right)+\beta_{3} \ln \left(g f c_{i j t}\right)+\beta_{4} \ln \left(l f p_{i j t}\right)+ \\
& \beta_{5} b_{i t} t_{i j t}+\beta_{6} t i p_{i j t}+\beta_{7} i n t r a \_f d i+\beta_{8} e x t r a \_i f d i+\beta_{9} e x t r a \_o f d i+\delta_{i j}+\gamma_{t}+\varepsilon_{i j t}
\end{aligned}
$$

where $i$ and $j$ are the recipient and investing countries of foreign direct investment, and $t$ is the time period (year). The dependent variable $f d i$ is bilateral inward foreign direct investment (ifdi) flow and stock and/or bilateral outward foreign direct investment ( $f d i$ ) flow and stock. The independent variables, $s g d p$, sim, $g f c$, and $l f p$, are based on the knowledge-capital model of FDI. $s g d p$ is the sum of gross domestic products of the recipient and investing countries. Countries with larger economic size are likely to invest abroad for access to market (market-seeking FDI) and/or access to the factor of production (resource seeking FDI). sim is the similarity in market sizes of the recipient and investing countries, calculated by $1-\left\{g d p_{i} /\left(g d p_{i}+g d p_{j}\right)\right\}^{2}-\left\{g d p_{j} /\left(g d p_{i}+g d p_{j}\right)\right\}^{2}$. Countries with similar market sizes tend to invest abroad for penetrating foreign markets. $g f c$ and $l f p$ are the endowment ratios of the recipient country to the investing country in physical capital and labor, respectively. Countries with similar factor endowments are likely to invest abroad for duplicating the same products, so-called horizontal FDI; and countries with different factor endowments tend to invest abroad for fragmenting production, so-called vertical FDI. According to the knowledge-capital model of FDI, the signs of coefficient $\beta_{1}$ and $\beta_{2}$ are expected to be positive, whereas the expected signs of coefficient $\beta_{3}$ and $\beta_{4}$ could be either positive or negative.

The independent variables, bit and tip, display a set of international investment agreement variables. bit is bilateral investment agreements between the recipient and investing countries categorized into three terms, (i) the ratifying BITs (bits) measured as a dummy variable (taking the value of unity when BITs is ratified), (ii) the cumulative number of BITs provisions (bit_all), and (iii) the cumulative number of various BITs provisions such as investment protection (bit_ptt), investment facilitation (bit_fct) and investment promotion (bit_pmt). Countries with bilateral investment agreements focusing on protecting the foreign investors, and facilitating and promoting the foreign investment tend to take these opportunities to invest in each other. tip is treaties with investment provisions categorized into two terms, (i) the cumulative number of the ratifying TIPs (tips), and (ii) the cumulative number of TIPs provisions. Countries with treaties with investment provisions are likely to invest abroad for gaining the investment benefits in each other. The investment coverage provisions of BITs and TIPs are in Table 1; and the measurement of the cumulative number of provisions relevant to investment protection, facilitation, and promotion are shown in Appendix A. BITs and TIPs are used to measure the respective effects on FDI, reflecting the significance of international investment negotiation for attracting foreign direct investment. The signs of coefficient $\beta_{5}$ and $\beta_{6}$ are expected to be positive. 
Table 1. BITs and TIPs provisions: description and coverage.

\begin{tabular}{|c|c|}
\hline Provisions & Areas/Coverages \\
\hline Preamble & $\begin{array}{l}\text { Reference to right to regulate; Reference to sustainable development; Reference to social } \\
\text { investment aspects; Reference to environmental aspects }\end{array}$ \\
\hline Scope and Definitions & $\begin{array}{l}\text { Definition of investment; Definition of the investor; Denial of benefits (DoB); Substantive } \\
\text { scope of the treaty; Temporal scope of the treaty }\end{array}$ \\
\hline Standards of Treatment & $\begin{array}{l}\text { National treatment }(\mathrm{NT}) * \text {; Most-favored-nation }(\mathrm{MFN}) \text { treatment } * \text {; Fair and equitable } \\
\text { treatment }(\mathrm{FET}) * \text {; Full protection and security }{ }^{*} \text {; Prohibition on unreasonable, arbitrary or } \\
\text { discriminatory measures; Expropriation Protection from strife; Transfer of funds }{ }^{*} \text {; Prohibition } \\
\text { of performance requirements (PRs) }{ }^{*} \text {; Umbrella clause *; Entry and sojourn of personnel; } \\
\text { Senior management (nationality) }\end{array}$ \\
\hline Other Clauses & $\begin{array}{l}\text { Transparency }{ }^{* *} ; \text { Health and environment }{ }^{* *} \text {; Labor standards } \\
\text { Corporate social responsibility }{ }^{* *} \text {; Corruption to regulate }{ }^{* *} ; \text { Not lowering of standards } \\
\text { clause }\end{array}$ \\
\hline Exceptions & $\begin{array}{l}\text { Essential security exception *; General public policy exceptions; Prudential carve-out } \\
\text { (concerns financial measures); Scheduling and reservations }\end{array}$ \\
\hline State-State Dispute Settlement & SSDS included * \\
\hline Investor-State Dispute Settlement & $\begin{array}{l}\text { ISDS included *; Alternatives to arbitration *; Scope and consent; Forums; Other specific } \\
\text { ISDS features }\end{array}$ \\
\hline Institutional Issues & $\begin{array}{l}\text { The mechanism for consultations between State parties ***; Institutional framework; Technical } \\
\text { cooperation/capacity building }\end{array}$ \\
\hline $\begin{array}{l}\text { Treaty Duration, Amendment } \\
\text { and Termination }\end{array}$ & Treaty duration; Automatic renewal; Amendment and termination \\
\hline
\end{tabular}

Note: ${ }^{*}{ }^{* *}$ and ${ }^{* * *}$ present investment protection, investment facilitation and investment promotion, respectively. Source: UNCTAD (2020b) and UNCTAD (2015).

The independent variables, intra_fdi, extra_ifdi, and extra_ofdi, capture the investment creation and diversion effect of regionalism that is considered on the ASEAN bloc in this study. intra_fdi is a dummy variable capturing the investment creation effect on intra-bloc FDI flow. It takes the value of unity when both recipient and investing countries have signed in regional economic agreement, and 0 otherwise. Countries with regional dependence (a single market and production base) are more likely to cherry-pick the benefits of regionalism by investing in each other member countries. The sign of coefficient $\beta_{7}$ is expected to be positive. extra_ifdi is a dummy variable capturing the investment effects on inward FDI flow from non-member countries in member countries (inward FDI creation or diversion). It takes the value of unity if the investing country is a non-member country and the recipient country is a member country, and 0 otherwise. extra_ofdi is also a dummy variable capturing the investment effects on outward FDI flow from members into non-members (outward FDI creation and diversion). It takes the value of unity if the recipient country is a non-member country and the investing country is a member country, and 0 otherwise. Countries without regional dependence are probably to more or less invest in member countries, indicating a stepping stone or stumbling block toward an investment policy framework for sustainable development (UNCTAD 2015). These variables are exploited to evaluate the investment creation and diversion effects of regionalism. The expected signs of coefficients $\beta_{8}$ and $\beta_{9}$ could be either positive or negative. The coefficient on the dummy variable is converted in the exponentiation of $\beta$ coefficient $\left(e^{\beta}-1 ; e=2.718\right)$ before interpreting. The variable $\delta_{i j}$ is a country-pair-specific fixed effect, $\gamma_{t}$ is a time-specific effect, and $\varepsilon_{i j t}$ is an error term.

\subsection{Data Source}

This study employs bilateral panel data for regression analysis drawn from all RCEP members consisting of ten ASEAN members (Brunei Darussalam, Cambodia, Indonesia, Lao People's Democratic Republic, Malaysia, Myanmar, the Philippines, Singapore, 
Thailand, and Vietnam) and five RCEP members (Australia, China including Hong Kong China, Japan, Republic of Korea, and New Zealand, hereafter RCEP-6) during the period 2009-2018. It amounts to a total of $16 \times 15 \times 10=2400$ observations. The research data are sourced as follows.

Data on bilateral inward FDI flow (ifdif) and stock (ifdis) and bilateral outward FDI flow (ofdif) and stock (ofdis) are obtained from the investment map database published by the International Trade Centre (ITC 2020), adjusted at constant 2010 thousand US dollars. Data on gross domestic products used to assess the sum of GDP ( $\operatorname{sgdp})$ and similarity in market size $(\mathrm{sim})$, and data on gross fixed capital used to measure relative capital endowment $(g f c)$, at constant 2010 million US dollars are gathered from the UNCTADStat data center published by the United Nations Conference on Trade and Development (UNCTAD 2020c). Data on labor force participation rate as a percentage of the total population aged 15 to 64 years used to measure relative labor endowment $(\mathrm{lfp})$ are from the World Development Indicators Databank published by the World Bank Group (World Bank 2020).

Data on bilateral investment treaties ratified and treaties with investment provision are obtained from the Investment Policy Hub and published by the United Nations Conference on Trade and Development (UNCTAD 2020b). The ratifying BITs (bits) are dummy variables, taking the value of unity with BITs ratified, whereas the number of ratifying TIPs (tips) is the summation of total TIPs ratified (see in Appendix B). Moreover, data on investment provisions of BITs and TIPs are obtained from the mapping of international investment agreements content were prepared by the Investment Policy Hub (UNCTAD 2020b). The contents of investment protection, investment facilitation, and investment promotion provisions were also well-extracted. The cumulative number of BITs provisions (bit_all) and TIPs provisions (tip_all) are measured by the summation of the degrees of total investment protection (e.g., concerning specific restrictions of protection for foreign investors and investment liberalization), investment facilitation (e.g., concerning the specific investment procedures and the reductions of investment barriers) and investment promotion (e.g., concerning the favorable investment incentives) provisions signed in BITs and TIPs, as shown in Tables A1 and A2. The cumulative number of BITs investment protection (bit_ptt), investment facilitation (bit_fct), and investment promotion (bit_pmt) are calculated by the summation of the degrees of total investment protection, facilitation, and promotion provisions, respectively. Recently, Alschner et al. (2020) introduced a new database on investment treaties, the so-called Electronic Database of Investment Treaties (EDIT). The EDIT is a comprehensive full-text database of international investment agreements. However, the contents of IIAs substantive provisions from the Investment Policy Hub are chosen in this study.

In addition, there are three FDI activities determined to analyze the investment creation and diversion effects of ASEAN regionalism: the FDI flow within ASEAN members (so-called intra-ASEAN FDI inflow), the FDI flow from RCEP-6 countries to ASEAN members (so-called extra-ASEAN FDI inflow), and the FDI flow from ASEAN members to RCEP-6 countries (so-called extra-ASEAN FDI outflow). The existences of intra-ASEAN FDI inflow (intra_fdi), extra-ASEAN FDI inflow (extra_ifdi), and extra-ASEAN FDI outflow (extra_ofdi) are defined as a dummy variable. The measurement is based on the FDI activities between the recipient and investing countries, taking the value of 1 whenever such activities occur. The descriptive statistics of the variables used in this study are expressed in Table 2. 
Table 2. Descriptive statistics of estimation model variables.

\begin{tabular}{|c|c|c|c|c|}
\hline Variables & Mean & Std. dev. & Min & Max \\
\hline $\ln$ (ifdif) & 5.11 & 5.96 & - & 18.53 \\
\hline $\ln$ (ifdis) & 5.14 & 6.80 & - & 21.01 \\
\hline $\ln$ (ofdif) & 3.80 & 5.75 & - & 18.70 \\
\hline $\ln$ (ofdis) & 2.16 & 3.74 & - & 21.01 \\
\hline $\ln (\operatorname{sgdp})$ & 13.95 & 1.43 & 9.65 & 16.93 \\
\hline $\ln (\operatorname{sim})$ & -0.63 & 1.52 & -6.21 & 0.69 \\
\hline $\ln (\mathrm{gfc})$ & - & 2.86 & -7.41 & 7.41 \\
\hline $\ln (\operatorname{lfp})$ & - & 0.13 & -0.36 & 0.36 \\
\hline bit_all & 10.6 & 2.96 & 0 & 14 \\
\hline tip_all & 6.3 & 9.62 & 0 & 21 \\
\hline bit_ptt & 8.68 & 2.32 & 0 & 10 \\
\hline bit_pmt & 0.12 & 0.33 & 0 & 1 \\
\hline bit_fct & 1.78 & 0.91 & 0 & 4 \\
\hline bits & 0.41 & 0.49 & 0 & 1 \\
\hline tips & 0.09 & 0.32 & 0 & 2 \\
\hline intra-fdi & 0.37 & 0.48 & 0 & 1 \\
\hline extra-ifdi & 0.25 & 0.43 & 0 & 1 \\
\hline extra-ofdi & 0.25 & 0.43 & 0 & 1 \\
\hline
\end{tabular}

Note: $\ln ($ ) is logarithm transformation. Number of observations are 2400. Source: Author's calculation.

\subsection{Estimators}

This study aims to examine the effects of international investment agreements on bilateral foreign investment by using the panel dataset that consists of bilateral FDI from ten ASEAN countries plus six RCEP countries ( 240 bilateral countries) for the period of 2009-2018 (10 years). This panel dataset represents several cross-sectional and time-series data. Thus, it is probably that our panel data regression model underlying the time-seriescross-section data may cause the problems of panel error and cross-sectional dependence, heterogeneity of variance, and autocorrelation of residuals. Therefore, the diagnostic tests to affirm the presence of multicollinearity, heteroskedasticity, and serial correlation on the variables must be first performed. Moreover, to avoid biased results in the panel data estimation, the Driscoll and Kraay (1998) Standard Errors (SCC) approach is used as a primary estimator in this study. The SCC allows the standard errors estimates assumed to be robust to disturbances that are heteroskedastic and autocorrelated (Hoechle 2007). Importantly, the SCC is able to remove the problem of heterogeneity from a large amount of cross-sectional data. The alternative estimators such as the Parks (1967) Feasible Generalized Least Squares (FGLS), Panel Corrected Standard Error approach (PCSE) suggested by Beck and Katz (1995), and Newey and West (1987) standard errors for coefficients (NEWEY) are used for the robustness check.

\section{Results}

\subsection{Are Foreign Direct Investment Flows Susceptible to the Investment Provisions in IIAs?}

The results of the Driscoll-Kraay standard errors estimation of the baseline model described in Equation (1) are displayed in Table 3. In these analyses, the primary focus is whether IIAs provisions affect bilateral foreign direct investment among the RCEP countries. The results of the estimation with bilateral inward FDI as the dependent variable are expressed in Models (1) to (4), whereas the results with bilateral outward FDI as the dependent variable are shown in Models (5) to (8).

Generally, the diagnostic tests of the models are first analyzed. The variance inflation factor (VIF) statistics of all independent variables in Models (1) to (8) are equal or below 3, indicating low multicollinearity problems. The Pesaran tests (under the null hypothesis of cross-sectional independence) in Models (1) to (8) show that the cross-sectional dependence in the errors is likely to arise in all panel data models. The modified Wald tests (under null hypothesis of panel homoskedasticity) in Models (1) to (8) reveal the presence of heteroskedasticity problems in all models. Finally, the Wooldridge tests (under the null 
hypothesis of no first-order autocorrelation) in Models (1) to (8) show the presence of the serial autocorrelation problems in all models. Therefore, the Driscoll-Kraay standard errors approach is employed to estimate the models of this study.

Table 3. Effects of international integration agreements on foreign direct investment in RCEP countries using SCC.

\begin{tabular}{|c|c|c|c|c|c|c|c|c|}
\hline & $\begin{array}{c}\text { Lifdif } \\
(1)\end{array}$ & $\begin{array}{l}\text { Lifdif } \\
(2)\end{array}$ & $\begin{array}{l}\text { Lifdis } \\
(3)\end{array}$ & $\begin{array}{l}\text { Lifdis } \\
(4)\end{array}$ & $\begin{array}{l}\text { Lofdif } \\
\text { (5) }\end{array}$ & $\begin{array}{c}\text { Lofdif } \\
\text { (6) }\end{array}$ & $\begin{array}{l}\text { Lofdis } \\
(7)\end{array}$ & $\begin{array}{c}\text { Lofdis } \\
\text { (8) }\end{array}$ \\
\hline Lsgdpij & $\begin{array}{l}1.86^{*} \\
(5.10)\end{array}$ & $\begin{array}{l}1.84 * \\
(5.10)\end{array}$ & $\begin{array}{l}1.60 * \\
(3.99)\end{array}$ & $\begin{array}{l}1.57 \text { * } \\
(3.91)\end{array}$ & $\begin{array}{l}0.60 * \\
(2.57)\end{array}$ & $\begin{array}{l}0.55 * \\
(2.35)\end{array}$ & $\begin{array}{l}0.34^{* *} \\
(1.76)\end{array}$ & $\begin{array}{c}0.21 \\
(1.13)\end{array}$ \\
\hline Lsimij & $\begin{array}{l}2.49 * \\
(5.02)\end{array}$ & $\begin{array}{l}2.44^{*} \\
(4.79)\end{array}$ & $\begin{array}{l}2.99 \text { * } \\
(3.23)\end{array}$ & $\begin{array}{l}2.73 \text { * } \\
(3.11)\end{array}$ & $\begin{array}{c}-0.08 \\
(-0.88)\end{array}$ & $\begin{array}{c}-0.05 \\
(-0.37)\end{array}$ & $\begin{array}{c}-0.01 \\
(-0.13)\end{array}$ & $\begin{array}{c}-0.03 \\
(-0.18)\end{array}$ \\
\hline Lgfcij & $\begin{array}{l}1.26^{*} \\
(7.03)\end{array}$ & $\begin{array}{l}1.23 * \\
(6.65)\end{array}$ & $\begin{array}{l}1.61 \text { * } \\
(3.56)\end{array}$ & $\begin{array}{l}1.43^{*} \\
(3.49)\end{array}$ & $\begin{array}{l}0.35 * \\
(3.56)\end{array}$ & $\begin{array}{l}0.36^{*} \\
(2.42)\end{array}$ & $\begin{array}{l}0.14^{* *} \\
(1.98)\end{array}$ & $\begin{array}{c}0.11 \\
(0.93)\end{array}$ \\
\hline Llfpij & $\begin{array}{l}7.93 * \\
(8.70)\end{array}$ & $\begin{array}{l}7.81 \text { * } \\
(9.12)\end{array}$ & $\begin{array}{l}7.33 * \\
(4.53)\end{array}$ & $\begin{array}{l}6.29 * \\
(3.06)\end{array}$ & $\begin{array}{c}9.25 * \\
(18.48)\end{array}$ & $\begin{array}{c}9.62 * \\
(21.38)\end{array}$ & $\begin{array}{l}4.94 * \\
(5.12)\end{array}$ & $\begin{array}{l}5.48 \text { * } \\
(4.21)\end{array}$ \\
\hline bit_all & $\begin{array}{l}0.15^{*} \\
(2.77)\end{array}$ & & $\begin{array}{l}0.10^{* *} \\
(2.23)\end{array}$ & & $\begin{array}{l}0.29 * \\
(3.67)\end{array}$ & & $\begin{array}{l}-0.11^{* *} \\
(-1.97)\end{array}$ & \\
\hline tip_all & $\begin{array}{l}0.15 * \\
(3.46)\end{array}$ & $\begin{array}{l}0.15^{*} \\
(3.46)\end{array}$ & $\begin{array}{l}0.16^{*} \\
(3.77)\end{array}$ & $\begin{array}{l}0.17 \text { * } \\
(3.98)\end{array}$ & $\begin{array}{c}-0.03^{* * *} \\
(-1.64)\end{array}$ & $\begin{array}{c}-0.03 \\
(-1.57) \\
(1.13)\end{array}$ & $\begin{array}{c}-0.01 \\
(-0.46)\end{array}$ & $\begin{array}{c}-0.01 \\
(-0.39)\end{array}$ \\
\hline bit_ptt & & $\begin{array}{l}0.14^{*} \\
(2.60)\end{array}$ & & $\begin{array}{l}0.27 * * \\
(2.33)\end{array}$ & & $\begin{array}{c}0.11 \\
(1.13)\end{array}$ & & $\begin{array}{l}-0.48^{* *} \\
(-2.28)\end{array}$ \\
\hline bit_pmt & & $\begin{array}{c}0.88^{*} \\
(4.16)\end{array}$ & & $\begin{array}{l}2.73^{*} \\
(4.20)\end{array}$ & & $\begin{array}{c}1.18^{* * *} \\
(1.68)\end{array}$ & & $\begin{array}{l}2.84^{*} \\
(7.64)\end{array}$ \\
\hline bit_fct & & $\begin{array}{c}0.12 \\
(0.87)\end{array}$ & & $\begin{array}{l}-0.70 * * \\
(-2.09)\end{array}$ & & $\begin{array}{l}0.85 \text { * } \\
(1.64)\end{array}$ & & $\begin{array}{l}0.95^{* *} \\
(2.16)\end{array}$ \\
\hline bit & $\begin{array}{c}-0.16 \\
(-0.64)\end{array}$ & $\begin{array}{c}-0.13 \\
(-0.53)\end{array}$ & $\begin{array}{l}0.70 \text { * } \\
(3.65)\end{array}$ & $\begin{array}{l}0.62 \text { * } \\
(2.83)\end{array}$ & $\begin{array}{l}0.58^{*} \\
(6.71)\end{array}$ & $\begin{array}{c}0.79^{*} \\
(12.04)\end{array}$ & $\begin{array}{l}0.42 \text { * } \\
(2.65)\end{array}$ & $\begin{array}{l}0.91 \text { * } \\
(8.99)\end{array}$ \\
\hline tip & $\begin{array}{l}1.88 \text { * } \\
(4.02)\end{array}$ & $\begin{array}{l}1.81 \text { * } \\
(3.96)\end{array}$ & $\begin{array}{l}1.07^{*} \\
(2.92)\end{array}$ & $\begin{array}{c}0.76^{* * *} \\
(1.75)\end{array}$ & $\begin{array}{c}-0.44 \\
(-0.81)\end{array}$ & $\begin{array}{c}-0.47 \\
(-0.76)\end{array}$ & $\begin{array}{l}-0.91 * \\
(-2.61)\end{array}$ & $\begin{array}{l}-1.10 \text { * } \\
(-2.63)\end{array}$ \\
\hline intra-ifdi & $\begin{array}{l}3.14^{*} \\
(3.41)\end{array}$ & $\begin{array}{l}3.11 \text { * } \\
(3.15)\end{array}$ & $\begin{array}{l}4.62 * \\
(4.00)\end{array}$ & $\begin{array}{l}3.85 * \\
(4.53)\end{array}$ & $\begin{array}{l}0.98 * \\
(3.75)\end{array}$ & $\begin{array}{l}1.46^{*} \\
(3.19)\end{array}$ & $\begin{array}{l}1.07^{*} \\
(2.44)\end{array}$ & $\begin{array}{l}1.96^{*} \\
(2.41)\end{array}$ \\
\hline extra-ifdi & $\begin{array}{l}2.68 \text { * } \\
(3.11)\end{array}$ & $\begin{array}{l}2.64 \text { * } \\
(2.85)\end{array}$ & $\begin{array}{l}4.88 \text { * } \\
(3.63)\end{array}$ & $\begin{array}{l}4.03 \text { * } \\
(4.01)\end{array}$ & $\begin{array}{l}-2.07 * \\
(-4.36)\end{array}$ & $\begin{array}{l}-2.07^{*} \\
(-4.82)\end{array}$ & $\begin{array}{l}-1.61 * \\
(-4.26)\end{array}$ & $\begin{array}{l}-1.66 * \\
(-4.61)\end{array}$ \\
\hline extra-ofdi & $\begin{array}{l}-0.78 * \\
(-7.64)\end{array}$ & $\begin{array}{l}-0.81 \text { * } \\
(-8.04)\end{array}$ & $\begin{array}{c}-0.08 \\
(-0.37)\end{array}$ & $\begin{array}{c}-0.23 \\
(-0.98)\end{array}$ & $\begin{array}{l}-0.35 \\
(-0.74)\end{array}$ & $\begin{array}{c}0.18 \\
(0.82)\end{array}$ & $\begin{array}{c}0.44^{* * *} \\
(1.62)\end{array}$ & $\begin{array}{l}1.46^{*} \\
(3.61)\end{array}$ \\
\hline Constant & $\begin{array}{l}-23.70 \text { * } \\
(-4.83)\end{array}$ & $\begin{array}{l}-23.42 \text { * } \\
(-4.85)\end{array}$ & $\begin{array}{l}-20.90 \text { * } \\
(-4.14)\end{array}$ & $\begin{array}{l}-20.42 \text { * } \\
(-4.10)\end{array}$ & $\begin{array}{l}-7.46^{* *} \\
(-2.15)\end{array}$ & $\begin{array}{l}-6.71^{* *} \\
(-2.01)\end{array}$ & $\begin{array}{c}0.36 \\
(0.16)\end{array}$ & $\begin{array}{c}2.29 \\
(0.98)\end{array}$ \\
\hline Observations & 2400 & 2400 & 2400 & 2400 & 2400 & 2400 & 2400 & 2400 \\
\hline $\mathrm{R}$-square & 0.36 & 0.36 & 0.29 & 0.31 & 0.11 & 0.12 & 0.03 & 0.06 \\
\hline Root MSE & 4.75 & 4.75 & 5.73 & 5.65 & 5.41 & 5.40 & 6.59 & 6.49 \\
\hline \multicolumn{9}{|c|}{ Diagnostic tests: } \\
\hline Pesaran's test & $76.35 *$ & $76.08 *$ & $97.48 *$ & $95.66 *$ & 96.31 * & $96.26 *$ & $129.23 *$ & $128.81 *$ \\
\hline Wald test & 16,074 * & 29,020 * & $68,942 *$ & 63,334 * & $93,000 *$ & 89,000 * & 330,000 * & 330,000 * \\
\hline Wooldridge test & $106^{*}$ & 105 * & 152 * & $152 *$ & $222 *$ & $222 *$ & 146 * & 145 * \\
\hline VIF & 2.98 & 3.00 & 2.98 & 3.00 & 2.98 & 3.00 & 2.98 & 3.00 \\
\hline
\end{tabular}

Note: $t$-statistics are in parentheses; ${ }^{*}$ significant with $p<0.01$; ${ }^{* *}$ significant with $p<0.05$; ${ }^{* * *}$ significant with $p<0.1$. Source: Author's calculation.

The results of the estimation with bilateral inward FDI, Models (1) to (4), most independent variables are statistically significant, implying that our selective variables affect bilateral inward FDI and the SCC estimation model is appropriate in explaining changes in foreign direct investment. There are three main sets of independent variables in these analyses: economic variables, international investment agreements variables, and regionalism variables.

First, the estimated coefficients of 'economic' variables (sum of GDP, the similarity in market size, relative capital endowment, and relative labor endowment) are positive and significant. A 1\% increase in GDP of the recipient and investing countries in the 
RCEP region is associated with an increase in bilateral inward FDI in RCEP countries of approximately $1.57-1.86 \%$. The findings are, as expected, that the recipient and investing countries integrated as a large factor market and production base are likely to attract them to invest in each other.

A $1 \%$ increase in similarity in GDP of the recipient and investing countries is more likely to increase bilateral inward FDI in the RCEP region by approximately $2.44-2.99 \%$. The similarity in the market size of the recipient and investing countries reflects the ability to share a specialization in production and to connect a unified supply chain of production. The higher the similarity in market size, the larger the inward FDI is. A $1 \%$ increase in relative capital endowment of the recipient country to the investing country in the RCEP region is related to an increase in bilateral inward FDI in the RCEP countries of approximately $1.23-1.61 \%$. Similarly, a $1 \%$ increase in relative labor abundance of the recipient country to the investing country in the RCEP region is more likely to increase bilateral inward FDI in the RCEP region by approximately 6.29-7.93\%. Relative factor endowments of the recipient and investing countries imply the level of the availability of factors of production on the one hand, and the FDI strategies, on the other hand. With the higher relative factors of production, foreign investors are highly encouraged to conduct horizontal FDI by replicating production activities abroad. All of these findings are relevant to the knowledge-capital model of FDI.

Second, most estimated coefficients of 'IIAs' variables are positive and significant. In Models (1) and (3), an increase in the number of BITs provisions between the recipient and investing countries in the RCEP region is associated with an increase in bilateral inward FDI flow in RCEP countries of approximately $0.10-0.15 \%$. Meanwhile, an increase in the number of TIPs provisions is also related to an increase in bilateral inward FDI flow of approximately $0.15-0.16 \%$. The BITs and TIPs contain the necessary investment provisions such as investment protection, facilitation, and promotion to achieve the mutual interests of member countries. These findings are in line with our hypothesis and follow Egger and Pfaffermayr (2004) and Egger and Merlo (2012) that suggested an increase in FDI and multinational activities being influenced by the ratifying BITs.

In Models (2) and (4), an increase in the number of investment protection provisions of BITs between the recipient and investing countries in the RCEP region is associated with an increase in bilateral inward FDI stock in ASEAN and RCEP-6 countries of approximately $0.14-0.27 \%$. Meanwhile, an increase in the number of investment promotion provisions of BITs causes an increase in bilateral inward FDI stock in RCEP countries of approximately $0.88-2.73 \%$. The BITs provisions on investment protection and promotion are regarded as incentive measures for foreign investors by attempting to build investor confidence, liberalize foreign investors' accessibility, and expand investment activities abroad. These findings are consistent with our hypothesis (H2) and pursue the recent work of Bengoa et al. (2020) that indicated that stronger investment protection provisions in BITs assisted to raise inward FDI. An increase in the number of investment facilitation provisions of BITs between the recipient and investing countries in the RCEP region is likely to decrease bilateral inward FDI stock by $0.70 \%$. Apparently, it contradicts the fact that the BITs provisions on investment facilitation involve uplifting the investment procedures of IIAs for improved investment efficiency and reduce the investment costs and barriers. Indeed, investment facilitation is one of the benefits of the entry of foreign investors, generally encouraging FDI activities.

Moreover, in Models (1) to (2), an increase in the number of TIPs between RCEP economies is related to an increase in bilateral inward FDI flow in ASEAN and RCEP-6 countries of $1.81-1.88 \%$. Surprisingly, the existence of BITs between RCEP countries is not significant to an increase in bilateral inward FDI flow. On the contrary, in Models (3) to (4), the presence of BITs is associated with an increase in bilateral inward FDI stock of approximately $85.88-101.36 \%\left(0.62<\beta_{6}<0.70\right)$, whereas an increase in the number of TIPs is related to an increase in bilateral inward FDI stock of $0.76-1.07 \%$. It indicates the importance of the establishment of BITs and TIPs on an increased inward FDI flow and 
stock. These results suggest, in line with our hypothesis (H1) that IIAs are likely to increase inward foreign direct investment. This evidence confirms the findings of Egger and Merlo (2012) that revealed the positive relationship between the ratifying BITs and an increased inward FDI, and Xiao (2011) that suggested the benefits of the investment provisions in the ASEAN-China investment agreement for member countries.

Finally, the estimated coefficients of 'regionalism' variables are both significantly positive and negative signs. The presence of FDI activities between ASEAN members is associated with an increase in bilateral inward FDI in RCEP countries of approximately $2141-10,044 \%\left(3.11<\beta_{7}<4.62\right)$. This variable may imply the role of ASEAN regionalism on bilateral inward FDI that member countries tend to take the advantages of the ASEAN investment agreements. The higher the intra-ASEAN FDI, the greater the bilateral inward FDI in all countries is. The presence of inward FDI activities from RCEP-6 to ASEAN countries is associated with an increase in bilateral inward FDI of approximately 1300 $13,056 \%\left(2.64<\beta_{8}<4.88\right)$. This variable could explain the levels of FDI attractiveness and investment climate in member countries from a non-member's perspective. Higher extra-ASEAN inward FDI enhances bilateral inward FDI due to the high FDI attractiveness and/or better investment climate in the ASEAN region. The presence of outward FDI activities from ASEAN to RCEP-6 countries is related to a decrease in bilateral inward FDI of approximately $118-124 \%\left(0.78<\beta_{9}<0.81\right)$. This variable could suggest the degree of member countries' investment capacity in non-member countries on the one hand; and the degree of the investment substitution or complementarity from member countries in non-member countries, on the other hand. Higher extra-ASEAN outward FDI lowers bilateral inward FDI due to the investment substitution effect against intra-ASEAN FDI. These findings are in line with our hypothesis (H3) and follow Baldwin et al. (2010) and Bengoa et al. (2020), who indicated that the formation of regional economic agreements causing both investment creation and diversion.

For comparison, Models (5) to (8) express the results of the estimation with bilateral outward FDI. Most estimated coefficients of 'IIAs' variables are statistically significant, implying that investment provisions of BITs are associated with bilateral outward FDI expansion and contraction. Some results are very similar to Models (1) to (4); for example, an increase in the number of investment facilitation provisions increases bilateral outward FDI. Estimated coefficients of the 'intra-ASEAN FDI' variable are positive and significant, while the coefficients of the 'extra-ASEAN inward FDI' variable are negative and significant. They reveal that FDI activities in ASEAN members stimulate bilateral outward FDI, but inward FDI activities from RCEP-6 to ASEAN countries tend to contract bilateral outward FDI. However, most findings are relevant to our hypotheses.

Overall, our empirical findings show that international investment agreements that include investment protection, facilitation, and promotion are a way to foster bilateral FDI in RCEP countries. They also display the relationship between the ASEAN regionalism and bilateral FDI that is a way to deal with the investment creation and diversion effect shown in the next subsection.

\subsection{Does the Membership of ASEAN Cause Investment Creation and Diversion?}

The special issue toward the estimated results shown in the previous subsection concerns the effect of the ASEAN membership on the presence of investment creation and diversion. To address this, the coefficients of intra- and extra-ASEAN FDI obtained in Table 3 are used to determine the values of investment creation and investment diversion (FDI effects). The definitions of investment creation and investment diversion refer to Baldwin et al. (2010) mentioned in the review section. There are three possibilities of intra-ASEAN and extra-ASEAN FDI effects, suggesting stepping stone or stumbling block toward an investment policy framework for sustainable development as shown in Table 4 .

The expected sign of $\beta_{7}$ coefficient is positive, suggesting the presence of 'investment creation' in ASEAN countries. The membership of ASEAN entails an inward FDI enlargement in the RCEP region. The sign of $\beta_{8}$ is positive, indicating the presence of 'inward FDI 
creation' from non-members to ASEAN members. The membership of ASEAN is likely to attract non-member investors and increases bilateral inward FDI in the RCEP region. On the contrary, if the sign of $\beta_{8}$ is negative, suggesting the presence of 'inward FDI diversion' from non-members to ASEAN members. The membership of ASEAN is unlikely to attract non-member investors and decreases bilateral inward FDI in the RCEP. The sign of $\beta_{9}$ is positive, indicating the presence of 'outward FDI creation' from ASEAN members to non-members; on the contrary, if it is negative, suggesting the presence of an 'outward FDI diversion'. As long as $\beta_{8}$ and $\beta_{9}$ are positive, the ASEAN membership is regarded as a stepping stone to capacity building on investment policies for sustainable development; but if they are negative, the ASEAN membership is a stumbling block. If either $\beta_{8}$ or $\beta_{9}$ is negative and the absolute negative value is less than the positive value, it implies a stepping stone. Conversely, if the absolute negative value is larger than the positive value, it implies a stumbling block toward investment policies for sustainable development.

Table 4. Investment creation and diversion and typology of investment blocs.

\begin{tabular}{|c|c|c|c|c|c|c|}
\hline \multicolumn{3}{|c|}{ Sign of Coefficients } & \multirow{2}{*}{$\begin{array}{l}\text { Intra-Bloc } \\
\text { FDI }\end{array}$} & \multirow{2}{*}{$\begin{array}{l}\text { Extra-Bloc } \\
\text { inward FDI }\end{array}$} & \multirow{2}{*}{$\begin{array}{c}\text { Extra-Bloc } \\
\text { outward FDI }\end{array}$} & \multirow{2}{*}{$\begin{array}{c}\text { Stepping Stone/Stumbling } \\
\text { Block }\end{array}$} \\
\hline$\beta_{7}$ & $\beta_{8}$ & $\beta_{9}$ & & & & \\
\hline+ & + & + & creation & creation & creation & Stepping stone \\
\hline+ & + & - & creation & creation & diversion & $\begin{array}{l}\text { Stepping stone if } \beta_{8}>\left|\beta_{9}\right| \\
\text { Stumbling block if } \beta_{8}<\left|\beta_{9}\right|\end{array}$ \\
\hline+ & - & + & creation & diversion & creation & $\begin{array}{l}\text { Stepping stone if }\left|\beta_{8}\right|<\beta_{9} \\
\text { Stumbling block if }\left|\beta_{8}\right|>\beta_{9}\end{array}$ \\
\hline+ & - & - & creation & diversion & diversion & Stumbling block \\
\hline
\end{tabular}

Source: Author's compilation.

Table 5 shows that the membership of ASEAN or the formation of IIAs renders the net investment creation effect and tends to support the international investment enlargement and the investment policy building for sustainable development. In Models (1) to (4), the effects from inward FDI activities from non-members to ASEAN members $\left(\beta_{8}\right)$ on bilateral inward FDI in the RCEP region (investment creation) are larger than the effects from outward FDI from ASEAN members to non-members ( $\beta_{9}$ ) (investment diversion). It implies that ASEAN's international investment agreements tend to support the entry into the UNCTAD international policy framework, as a stepping stone toward sustainable development. These findings are in line with our hypothesis (H3) and follow Bengoa et al. (2020); Tanaka and Arita (2016); Park and Park (2009); and Kreinin and Plummer (2008).

Table 5. Investment creation and diversion in intra-ASEAN and extra-ASEAN FDI.

\begin{tabular}{|c|c|c|c|c|c|c|c|}
\hline \multirow{2}{*}{ Model } & \multicolumn{3}{|c|}{ Coefficients } & \multirow{2}{*}{ Intra-ASEAN FDI } & \multirow{2}{*}{$\begin{array}{l}\text { Extra-ASEAN } \\
\text { inward FDI }\end{array}$} & \multirow{2}{*}{$\begin{array}{l}\text { Extra-ASEAN } \\
\text { outward FDI }\end{array}$} & \multirow{2}{*}{$\begin{array}{c}\text { Stepping } \\
\text { Stone/Stumbling Block }\end{array}$} \\
\hline & $\beta_{7}$ & $\beta_{8}$ & $\beta_{9}$ & & & & \\
\hline 1 & 3.14 & 2.68 & -0.78 & creation & creation & diversion & Stepping stone \\
\hline 2 & 3.11 & 2.64 & -0.81 & creation & creation & diversion & Stepping stone \\
\hline 3 & 4.62 & 4.88 & -0.08 & creation & creation & diversion & Stepping stone \\
\hline 4 & 3.85 & 4.03 & -0.23 & creation & creation & diversion & Stepping stone \\
\hline 5 & 0.98 & -2.07 & -0.35 & creation & creation & creation & Stepping stone \\
\hline 6 & 1.46 & -2.07 & 0.18 & creation & creation & diversion & Stepping stone \\
\hline 7 & 1.07 & -1.61 & 0.44 & creation & creation & diversion & Stepping stone \\
\hline 8 & 1.96 & -1.66 & 1.46 & creation & creation & diversion & Stepping stone \\
\hline
\end{tabular}

Note: Models (1) to (4) focus on bilateral inward FDI. Models (5) to (8) focus on bilateral outward FDI.

Furthermore, the $\beta_{8}$ and $\beta_{9}$ coefficients of Models (5) and (8) exhibit the effects of extraASEAN inward and outward FDI on bilateral outward FDI in the RCEP region, respectively. These empirical results could reflect an investment creation with a decrease in bilateral outward FDI (an increase in capital stock) and an investment diversion with an increase in bilateral outward FDI (a decrease in capital stock). The effects from extra-ASEAN inward 
FDI $\left(\beta_{8}\right)$ on bilateral outward FDI (investment creation) are larger than the effects from extra-ASEAN outward FDI $\left(\beta_{9}\right)$ on bilateral outward FDI (investment diversion), i.e., the ASEAN regionalism is unlikely to hinder the international policy framework for sustainable development.

In summary, bilateral foreign direct investments in ASEAN and RCEP-6 countries would cause 'investment creation' rather than 'investment diversion'. In other words, the wave of enlarged regionalism is a stepping stone on the road to the international policy framework for sustainable development suggested by the UNCTAD.

\subsection{How do Investment Provisions in IIAs Impact Intra-ASEAN FDI and Extra-ASEAN FDI?}

As the next step in our analysis, we examine whether the investment provisions in IIAs provide a plausible explanation for the differences in inward foreign direct investment across intra-ASEAN and extra-ASEAN countries.

In the first column of Table 6, the results of investment provisions of IIAs on intraASEAN inward FDI flow are presented. As expected, intra-ASEAN inward FDI flow tends to increase significantly with the investment protection and facilitation provisions in BITs and the investment provisions in TIPs. Surprisingly, the investment promotion provisions have a negative and significant effect on intra-ASEAN inward FDI flow.

Table 6. Effects of IIAs on intra-ASEAN inward FDI and extra-ASEAN inward FDI.

\begin{tabular}{|c|c|c|c|c|c|c|c|c|}
\hline & \multicolumn{4}{|c|}{ Intra-ASEAN inward FDI } & \multicolumn{4}{|c|}{ Extra-ASEAN inward FDI } \\
\hline & $\begin{array}{l}\text { Lifdif } \\
\text { (1) }\end{array}$ & $\begin{array}{l}\text { Lifdis } \\
\text { (2) }\end{array}$ & $\begin{array}{l}\text { Lofdif } \\
\text { (3) }\end{array}$ & $\begin{array}{l}\text { Lofdis } \\
\text { (4) }\end{array}$ & $\begin{array}{l}\text { Lifdif } \\
\text { (5) }\end{array}$ & $\begin{array}{l}\text { Lifdis } \\
\text { (6) }\end{array}$ & $\begin{array}{c}\text { Lofdif } \\
\text { (7) }\end{array}$ & $\begin{array}{l}\text { Lofdis } \\
\text { (8) }\end{array}$ \\
\hline \multirow{2}{*}{ Lsgdpij } & $2.25 *$ & $2.64 *$ & 0.37 & 0.31 & $2.62 *$ & $3.18 *$ & -0.23 & -0.14 \\
\hline & $(5.97)$ & $(5.26)$ & $(1.29)$ & $(1.08)$ & $(8.20)$ & $(6.77)$ & $(-1.14)$ & $(-0.98)$ \\
\hline \multirow{2}{*}{ Lsimij } & $2.55 *$ & $3.14 *$ & -0.33 & $-1.09 *$ & $1.73 *$ & $2.42 * *$ & $0.85 *$ & $1.86 *$ \\
\hline & $(4.10)$ & $(2.65)$ & $(-1.22)$ & $(-6.82)$ & $(2.73)$ & $(1.97)$ & $(3.56)$ & $(8.30)$ \\
\hline \multirow{2}{*}{ Lgfcij } & $1.45 *$ & $2.31 *$ & 0.10 & $-0.68 *$ & $1.53 *$ & $2.39 *$ & 0.70 * & 0.64 * \\
\hline & $(5.66)$ & $(3.55)$ & $(0.43)$ & $(-4.61)$ & $(6.95)$ & $(4.20)$ & $(5.23)$ & $(7.66)$ \\
\hline \multirow{2}{*}{ Llfpij } & $7.77 *$ & 13.75 * & $14.94^{*}$ & $5.20^{* *}$ & $18.69 *$ & $23.65 *$ & $4.77^{*}$ & $-6.37^{*}$ \\
\hline & (19.38) & (10.61) & $(8.54)$ & $(2.27)$ & $(16.20)$ & (19.24) & (5.84) & $(-4.90)$ \\
\hline \multirow{2}{*}{ tip_all } & $0.15 *$ & 0.16 * & -0.01 & -0.03 & $0.19 *$ & $0.19 *$ & 0.009 & 0.02 \\
\hline & (3.89) & $(3.89)$ & $(-0.76)$ & $(-1.07)$ & (3.85) & $(3.81)$ & $(0.53)$ & $(0.11)$ \\
\hline \multirow{2}{*}{ bit_ptt } & 0.09 & -0.09 & 0.05 & -0.49 * & 0.09 & -0.14 & $0.73 *$ & $7.25 *$ \\
\hline & $(1.31)$ & $(-0.89)$ & $(0.71)$ & $(-2.46)$ & $(0.73)$ & $(-1.00)$ & (12.05) & $(38.01)$ \\
\hline \multirow{2}{*}{ bit_pmt } & $-2.23^{* *}$ & -2.05 & $3.69 *$ & $3.53 *$ & $-2.69 * *$ & -2.52 & $-1.65 *$ & $-1.16^{*}$ \\
\hline & $(-2.13)$ & $(-1.25)$ & $(3.96)$ & $(20.47)$ & $(-1.95)$ & $(-1.31)$ & $(-3.03)$ & $(-2.56)$ \\
\hline \multirow{2}{*}{ bit_fct } & $0.73^{* * *}$ & 1.74 * & $0.81^{* *}$ & $0.95 *$ & $1.11^{* * *}$ & $2.18 *$ & $-2.24 *$ & -0.002 \\
\hline & $(1.90)$ & $(3.25)$ & $(2.16)$ & $(2.63)$ & (1.87) & $(3.49)$ & $(-8.97)$ & $(-0.09)$ \\
\hline \multirow{2}{*}{ bit } & $0.40^{* * *}$ & 1.82 * & $1.43^{*}$ & 1.01 * & $0.36^{*}$ & 1.59 * & $2.35 *$ & -0.05 \\
\hline & (1.68) & (7.94) & (11.12) & (3.64) & $(4.84)$ & $(4.57)$ & (3.99) & $(-0.11)$ \\
\hline \multirow{2}{*}{ tip } & $3.32 *$ & 2.99 * & $-1.06^{*}$ & $-1.40 * *$ & $1.03^{* *}$ & 1.89 * & 0.93 & -0.42 \\
\hline & (15.14) & (7.81) & $(-3.83)$ & $(-2.19)$ & (1.94) & $(2.69)$ & (1.21) & $(-0.39)$ \\
\hline \multirow{2}{*}{ Constant } & $-25.90 *$ & $-30.51 *$ & -3.16 & 2.63 & -32.53 * & -38.66 * & 3.74 & $8.84 *$ \\
\hline & $(-6.83)$ & $(-5.23)$ & $(-0.99)$ & $(0.77)$ & $(-9.04)$ & $(-6.72)$ & (1.36) & $(3.07)$ \\
\hline Observations & 900 & 900 & 900 & 900 & 590 & 590 & 590 & 590 \\
\hline R-square & 0.38 & 0.40 & 0.19 & 0.06 & 0.48 & 0.48 & 0.17 & 0.12 \\
\hline Root MSE & 4.29 & 4.99 & 5.28 & 6.82 & 4.35 & 5.17 & 5.20 & 6.74 \\
\hline \multicolumn{9}{|c|}{ Diagnostic tests: } \\
\hline Pesaran's test & $32.71 *$ & $39.52 *$ & $29.09 *$ & $32.34 *$ & $37.96 *$ & $37.61 *$ & $26.63 *$ & $33.67 *$ \\
\hline Wald test & $2753 *$ & $15,271 *$ & $44,000 *$ & $27,000 *$ & $1642 *$ & $8308 *$ & $130,000 *$ & 200,000 * \\
\hline Wooldridge test & $158 *$ & $1930 *$ & $54 *$ & 76 * & $521 *$ & $1161 *$ & $59 *$ & $75 *$ \\
\hline VIF & 2.59 & 2.59 & 2.59 & 2.59 & 2.13 & 2.13 & 2.13 & 2.13 \\
\hline
\end{tabular}

Note: $t$-statistics are in parentheses; ${ }^{*}$ significant with $p<0.01 ;{ }^{* *}$ significant with $p<0.05$; ${ }^{* * *}$ significant with $p<0.1$. Source: Author's calculation. 
Column (5) depicts the results of investment provisions of IIAs on extra-ASEAN inward FDI flow. We still find that the investment facilitation provisions in BITs, and the investment provisions in TIPs have positive and significant effects on extra-ASEAN inward FDI flow. Similarly, we found that the investment facilitation provisions in BITs and the investment provisions in TIPs have positive and significant effects on intra-ASEAN inward FDI stock, while the investment promotion provisions in BITs have a negative and insignificant effect on bilateral intra-ASEAN inward FDI stock (Column (2) and (6)). No matter whether the ASEAN exists, ASEAN members could attract foreign investors in both the ASEAN region and the RCEP region. That means the high levels of foreign investor confidence and investment climate in ASEAN countries. Moreover, ASEAN members should pay more attention to capacity building on investment facilitation provisions in IIAs to foster an increase in intra-ASEAN and extra-ASEAN inward FDI.

Similar to what we do for the analysis by inward FDI, in Columns (3) and (4), intraASEAN outward FDI increases significantly with investment promotion and facilitation provisions in BITs. The results also confirm the significance of investment provisions, especially investment promotion and facilitation in attracting the entry of foreign investors within the ASEAN region. However, an extra-ASEAN outward FDI increases significantly with investment protection provisions in BITs and decreases significantly with investment promotion provisions in BITs (Column (8)). These results indicate the significance of RCEP- 6 countries on behalf of the investing counties and recipient countries. The effects could also reflect the insufficient investment provisions in attracting intra-ASEAN FDI and the absence of international investment agreements for serving foreign investors (extra-ASEAN FDI).

In summary, most investment provisions in IIAs are likely to affect intra-ASEAN foreign direct investment, whereas they are less likely to impact extra-ASEAN FDI. Accordingly, in order to achieve the UNCTAD investment policies for sustainable development, investment provisions in IIAs should be improved; meanwhile, the international investment agreements should be extended.

\subsection{Robustness Checks}

To check the robustness of the baseline results, we employ alternative estimators in estimating the model in order to address the sensitivity of endogeneity problems. The alternative estimation methods are the Parks (1967) Feasible Generalized Least Squares (FGLS), Panel corrected standard error approach (PCSE) estimator, and Newey-West standard errors for coefficients (NEWEY) estimator. Table 7 shows a series of robust estimated results for the effects of international investment agreements on bilateral inward and outward foreign direct investment. Based on Model (2) in Table 3, the coefficients of the model using the FGLS, PCSE, and NEWEY estimators are shown in Column (1) to (3), respectively. The results are generally consistent with our baseline model. Economic factors i.e., market size, the similarity in market sizes, and the similarity in capital and labor endowments as well as IIAs factors i.e., investment promotion provision of BITs and TIPs provisions have positive and significant effects on bilateral inward FDI in RCEP countries. The findings also suggest that intra-ASEAN FDI and extra-ASEAN inward FDI stimulate bilateral inward FDI in the RCEP region; on the contrary, extra-ASEAN outward FDI lowers bilateral inward FDI in the RCEP region. In addition, Column (4) to (6) show the estimated coefficients on the variables from Model (4) in Table 3. The results are consistent with our earlier baseline findings. 
Table 7. Robustness results of the effect of IIAs on bilateral inward and outward FDI.

\begin{tabular}{|c|c|c|c|c|c|c|}
\hline & \multicolumn{3}{|c|}{ Lifdif } & \multicolumn{3}{|c|}{ Lofdif } \\
\hline & $\begin{array}{l}\text { FGLS } \\
\text { (1) }\end{array}$ & $\begin{array}{l}\text { PCSE } \\
\text { (2) }\end{array}$ & $\begin{array}{l}\text { NEWEY } \\
\text { (3) }\end{array}$ & $\begin{array}{l}\text { FGLS } \\
\text { (4) }\end{array}$ & $\begin{array}{l}\text { PCSE } \\
(5)\end{array}$ & $\begin{array}{c}\text { NEWEY } \\
\text { (6) }\end{array}$ \\
\hline Lsgdpij & $\begin{array}{c}2.17^{*} \\
(22.14)\end{array}$ & $\begin{array}{l}1.84^{*} \\
(7.75)\end{array}$ & $\begin{array}{l}1.84^{*} \\
(18.20)\end{array}$ & $\begin{array}{l}0.005 \\
(0.10)\end{array}$ & $\begin{array}{l}0.55^{*} \\
(2.67)\end{array}$ & $\begin{array}{l}0.55^{*} \\
(4.71)\end{array}$ \\
\hline Lsimij & $\begin{array}{l}3.05 * \\
(16.68)\end{array}$ & $\begin{array}{l}2.44^{*} \\
(7.69)\end{array}$ & $\begin{array}{l}2.44^{*} \\
(15.28)\end{array}$ & $\begin{array}{l}-0.029 \\
(-0.31)\end{array}$ & $\begin{array}{l}-0.05 \\
(-0.35)\end{array}$ & $\begin{array}{c}-0.05 \\
(-0.28)\end{array}$ \\
\hline Lgfcij & $\begin{array}{l}1.68^{*} \\
(14.72)\end{array}$ & $\begin{array}{l}1.23 * \\
(8.97)\end{array}$ & $\begin{array}{l}1.23 * \\
(12.93)\end{array}$ & $\begin{array}{l}0.0004 \\
(0.01)\end{array}$ & $\begin{array}{l}0.36^{*} \\
(2.78)\end{array}$ & $\begin{array}{l}0.36^{*} \\
(3.41)\end{array}$ \\
\hline Llfpij & $\begin{array}{l}6.40 * \\
(7.46)\end{array}$ & $\begin{array}{l}7.81^{*} \\
(9.71)\end{array}$ & $\begin{array}{l}7.81 * \\
(9.45)\end{array}$ & $\begin{array}{l}1.14^{*} \\
(2.58)\end{array}$ & $\begin{array}{c}9.62 * \\
(19.91)\end{array}$ & $\begin{array}{l}9.62 * \\
(9.47)\end{array}$ \\
\hline tip_all & $\begin{array}{l}0.01 \text { ** } \\
(2.32)\end{array}$ & $\begin{array}{l}0.15^{*} \\
(3.29)\end{array}$ & $\begin{array}{l}0.15^{*} \\
(14.94)\end{array}$ & $\begin{array}{c}-0.00002 \\
(-0.01)\end{array}$ & $\begin{array}{l}-0.03 \\
(-1.41)\end{array}$ & $\begin{array}{l}-0.03 * \\
(-3.03)\end{array}$ \\
\hline bit_ptt & $\begin{array}{c}0.06 \\
(1.18)\end{array}$ & $\begin{array}{l}0.14^{* *} \\
(2.13)\end{array}$ & $\begin{array}{l}0.14 \text { * } \\
(3.11)\end{array}$ & $\begin{array}{c}0.06 \\
(1.49)\end{array}$ & $\begin{array}{c}0.11 \\
(0.92)\end{array}$ & $\begin{array}{c}0.11^{* * *} \\
(1.83)\end{array}$ \\
\hline bit_pmt & $\begin{array}{c}0.53^{* * *} \\
(1.62)\end{array}$ & $\begin{array}{l}0.88^{*} \\
(4.34)\end{array}$ & $\begin{array}{l}0.88^{*} \\
(2.44)\end{array}$ & $\begin{array}{l}1.74 \text { * } \\
(5.10)\end{array}$ & $\begin{array}{l}1.18^{* *} \\
(2.18)\end{array}$ & $\begin{array}{l}1.18^{*} \\
(3.21)\end{array}$ \\
\hline bit_fct & $\begin{array}{l}-0.25 \\
(-1.27)\end{array}$ & $\begin{array}{c}0.12 \\
(0.98)\end{array}$ & $\begin{array}{c}0.12 \\
(0.77)\end{array}$ & $\begin{array}{l}-0.19 \\
(-1.41)\end{array}$ & $\begin{array}{l}0.85^{* *} \\
(2.08)\end{array}$ & $\begin{array}{l}0.85 * \\
(3.99)\end{array}$ \\
\hline bit & $\begin{array}{l}-0.02 \\
(-0.09)\end{array}$ & $\begin{array}{l}-0.13 \\
(-0.77)\end{array}$ & $\begin{array}{c}-0.13 \\
(-0.58)\end{array}$ & $\begin{array}{c}0.17 \\
(1.11)\end{array}$ & $\begin{array}{l}0.79 * \\
(8.48)\end{array}$ & $\begin{array}{l}0.79 * \\
(3.09)\end{array}$ \\
\hline tip & $\begin{array}{l}1.46^{*} \\
(4.49)\end{array}$ & $\begin{array}{l}1.81 * \\
(3.81)\end{array}$ & $\begin{array}{l}1.81 * \\
(5.34)\end{array}$ & $\begin{array}{c}-0.04 \\
(-0.45)\end{array}$ & $\begin{array}{c}-0.47 \\
(-0.91)\end{array}$ & $\begin{array}{c}-0.47 \\
(-1.23)\end{array}$ \\
\hline intra-ifdi & $\begin{array}{l}3.51 * \\
(6.70)\end{array}$ & $\begin{array}{l}3.11 * \\
(4.31)\end{array}$ & $\begin{array}{l}3.11 * \\
(6.59)\end{array}$ & $\begin{array}{c}0.23 \\
(0.76)\end{array}$ & $\begin{array}{l}1.46^{*} \\
(3.05)\end{array}$ & $\begin{array}{l}1.46^{*} \\
(2.91)\end{array}$ \\
\hline extra-ifdi & $\begin{array}{l}3.96^{*} \\
(7.43)\end{array}$ & $\begin{array}{l}2.64^{*} \\
(4.16)\end{array}$ & $\begin{array}{l}2.64^{*} \\
(5.88)\end{array}$ & $\begin{array}{l}-0.10 \\
(-0.43)\end{array}$ & $\begin{array}{l}-2.07^{*} \\
(-6.30)\end{array}$ & $\begin{array}{l}-2.07^{*} \\
(-4.73)\end{array}$ \\
\hline extra-ofdi & $\begin{array}{c}-0.68 \\
(-1.41)\end{array}$ & $\begin{array}{l}-0.81 * \\
(-3.09)\end{array}$ & $\begin{array}{c}-0.81^{* * *} \\
(-1.84)\end{array}$ & $\begin{array}{c}-0.05 \\
(-0.18)\end{array}$ & $\begin{array}{c}0.18 \\
(0.54)\end{array}$ & $\begin{array}{c}0.18 \\
(0.39)\end{array}$ \\
\hline Constant & $\begin{array}{l}-25.95 * \\
(-17.52)\end{array}$ & $\begin{array}{l}-23.42 * \\
(-6.48)\end{array}$ & $\begin{array}{l}-23.42 * \\
(-15.75)\end{array}$ & $\begin{array}{l}0.007 \\
(0.01)\end{array}$ & $\begin{array}{l}-6.71 \\
(-2.44)\end{array}$ & $\begin{array}{l}-6.71 * \\
(-3.90)\end{array}$ \\
\hline $\begin{array}{c}\text { Observations } \\
\text { R-square }\end{array}$ & 2400 & 2400 & 2400 & & 2400 & 2400 \\
\hline Wald test & 129 * & 9323 * & & 57 * & 3128 * & \\
\hline F-test & & & $166^{*}$ & & & $34.60 *$ \\
\hline
\end{tabular}

Note: $t$-statistics are in parentheses; ${ }^{*}$ significant with $p<0.01 ;{ }^{* *}$ significant with $p<0.05$; ${ }^{* * *}$ significant with $p<0.1$. Source: Author's calculation.

\section{Concluding Remarks}

This study focuses on the effects of investment provisions in international investment agreements on bilateral foreign direct investment in RCEP countries including the investment effects of the ASEAN membership toward the UNCTAD investment policies for sustainable development. The annual panel data on 16 RCEP countries during the period 2009 to 2018 and the Driscoll-Kraay standard errors estimator are employed to investigate the effects of economic, IIAs, and regionalism variables on bilateral FDI. Most estimated results show that the economic variables, as well as the IIAs variables, are significant with the expected signs. The results also indicate that investment provisions in BITs and TIPs have positive and significant effects on inward FDI in the RCEP region. Overall, investment provisions in IIAs (bilateral investment treaties and treaties for investment provisions) such as investment protection, facilitation, and promotion are a strategic policy instrument to increase inward FDI in both the ASEAN region and the RCEP region.

Moreover, the findings suggest a significant positive correlation between intra-ASEAN FDI and bilateral inward FDI, implying the investment creation within ASEAN countries. Extra-ASEAN inward FDI has a positive and significant effect on bilateral inward FDI, suggesting the investment creation between ASEAN members and RCEP-6 countries. Meanwhile, extra-ASEAN outward FDI has a negative and significant effect on bilateral FDI, indicating the investment diversion against RCEP- 6 countries. Interestingly, the investment 
effects between ASEAN members and RCEP-6 countries seem to be particularly a stepping stone on the road to the investment policy framework for sustainable development. This paper provides three contributions. First, it highlights how investment provisions in IIAs on bilateral FDI in the RCEP region being the present largest regional bloc in the world. Second, unlike other papers that define the IIAs variables from the number of investment protection provisions, this study categorizes investment provisions in IIAs into three areas: investment protection, facilitation, and promotion provisions and measures them in terms of the cumulative number of such investment provisions. Finally, this paper contributes to the literature by analyzing the investment effects of intra-and extra-bloc FDI activities on bilateral FDI that are engaged in supporting or hindering the international investment agreements extension and/or investment policy framework for sustainable development.

From the policy perspective, our empirical results suggest that an improved foreign investment relationship in the Asia Pacific region is important. The regional comprehensive economic partnership (RCEP) agreement signed in 2020 covering treaties with investment provisions can be used as a strategic policy instrument, while investment provisions should be embraced investment protection, liberalization, facilitation, and promotion. To date, the RCEP agreement is not in force yet. These investment provisions should be promptly exploited in order to increase foreign direct investment flows in members. At the same time, we find that in some cases, investment promotion and facilitation provisions in IIAs are unlikely to support foreign investors. Policymakers should offer and adopt tailoredmade investment policies straight away rather than regular investment provisions in IIAs. Likewise, the investment protection provision in IIAs should be enacted efficiently, effectively, and in accordance with the national investment protection measures. In addition, our empirical evidence also indicates the deeper the regional economic agreement with related-investment provisions, the larger the investment creation effects occur. Member countries in the RCEP region should be aware of the fact that investment provisions in TIPs can complement BITs provisions but they cannot be a substitute for them. Hence, the RCEP members should make efforts to avoid the effects of the overlapping and inconsistent investment-related provisions. Most importantly, the IIA regime should pursue the UNCTAD's investment policy framework for sustainable investment.

However, this study has some limitations. We only concentrate on the effects of the international investment agreements on bilateral FDI in the RCEP countries. Indeed, there still are a lot of international investment agreements that should be analyzed for comparative literature. Moreover, in the light of the efficiency of international investment provisions in IIAs, future research would focus on analyzing the effects of the efficiency of investment provisions on the entry of foreign investors. In fact, the number of investor-state dispute settlement cases can reflect the quality of the international investment provisions in IIAs. Further research would focus on the implications of the quality of international investment agreements on FDI attractiveness. Finally, future research should shed light on the policy implications of our research findings.

Funding: This research received no external funding.

Data Availability Statement: The data used in this paper are available from the investment map database (https://www.investmentmap.org [accessed on 15 November 2020]), The Investment Trade Centre; the UNCTADStat (https:/ / unctadstat.unctad.org/EN/Index.html [accessed on 15 November 2020]) and the investment policy hub (https: / investmentpolicy.unctad.org/internationalinvestment-agreements /iia-mapping [accessed on 15 November 2020]), The United Nations Conference on Trade and Development; and the world development indicators (https://databank. worldbank.org/reports.aspx?source=world-development-indicators [accessed on 15 November 2020]), The World Bank Group.

Acknowledgments: The author thanks two anonymous reviewers and the editor for their valuable comments and suggestions. This work was supported by Mae Fah Luang University, Thailand.

Conflicts of Interest: The author declares no conflict of interest. 


\section{Appendix A. Level of Investment Provisions in BITs and TIPs}

Tables A1 and A2 display the levels of investment protection provisions and investment facilitation and promotion provisions in BITs and TIPs, respectively, as measured by UNCTAD (2020b). The measurement of the level of investment provisions is based on the presence of investment protection, facilitation, and promotion provisions in BITs and TIPs, taking the value of 1 whenever such investment provisions exist. High and low levels of investment provisions depend on the cumulative number of investment provisions in each BITs and TIPs.

Table A1. Level of investment protection provisions in BITs and TIPs.

\begin{tabular}{|c|c|c|}
\hline No. & Provisions & $\begin{array}{c}\text { Level } \\
(1=\text { High, } 0=\text { Low })\end{array}$ \\
\hline & $\begin{array}{l}\text { Standards of treatment } \\
\text { Type of national treatment clause: }\end{array}$ & \\
\hline 1 & Pre-establishment & Yes (1)/No (0) \\
\hline 2 & $\begin{array}{l}\text { Post establishment } \\
\text { Type of most-favored nation (MFN) treatment clause: }\end{array}$ & Yes (1)/No (0) \\
\hline 3 & Pre-establishment & Yes (1)/No (0) \\
\hline 4 & $\begin{array}{l}\text { Post establishment } \\
\text { Fair and equitable treatment (FET)" }\end{array}$ & Yes (1)/No (0) \\
\hline 5 & $\begin{array}{l}\text { FET qualified } \\
\text { By reference to international law or by listing FET elements: }\end{array}$ & Yes (1)/No (0) \\
\hline 6 & $\begin{array}{l}\text { Full protection and security } \\
\text { Standard or with reference to domestic law: }\end{array}$ & Yes (1)/No (0) \\
\hline 7 & Indirect expropriation defined & Yes (0)/No (1) \\
\hline 8 & Transfer of funds included & Yes (1)/No (0) \\
\hline 9 & Prohibition of performance requirements included & Yes $(0) /$ No $(1)$ \\
\hline 10 & $\begin{array}{l}\text { Umbrella clause } \\
\text { Exceptions }\end{array}$ & Yes (1)/No (0) \\
\hline 11 & $\begin{array}{l}\text { Essential security exception included } \\
\text { State-State Dispute Settlement (SSDS) }\end{array}$ & Yes (0)/No (1) \\
\hline 12 & $\begin{array}{l}\text { SSDS included } \\
\text { Investor-State Dispute Settlement (ISDS) }\end{array}$ & Yes (1)/No (0) \\
\hline 13 & $\begin{array}{l}\text { ISDS included } \\
\text { Alternatives to arbitration }\end{array}$ & Yes (1)/No (0) \\
\hline 14 & $\begin{array}{l}\text { A. Voluntary Alternative Dispute Resolution } \\
\text { B. Compulsory Alternative Dispute Resolution } \\
\text { C. None }\end{array}$ & $\mathrm{A}(1) / \mathrm{B}(0.5) / \mathrm{C}(0)$ \\
\hline
\end{tabular}

Source: UNCTAD (2020b).

Table A2. Level of investment facilitation and promotion provisions in BITs and TIPs.

\begin{tabular}{|c|c|c|}
\hline No. & Provisions & $\begin{array}{c}\text { Level } \\
(1=\text { High }, 0=\text { Low })\end{array}$ \\
\hline & Other Clauses & \\
\hline 1 & $\begin{array}{l}\text { Transparency directed at States } \\
\text { (obligation to publish laws and regulations) }\end{array}$ & Yes (1)/No (0) \\
\hline 2 & Transparency directed at investors & Yes (1)/No (0) \\
\hline 3 & Health and environment & Yes (1)/No (0) \\
\hline 4 & Labor standards & Yes (1)/No (0) \\
\hline 5 & Right to regulate & Yes (1)/No (0) \\
\hline 6 & Corporate social responsibility & Yes (1)/No (0) \\
\hline 7 & Corruption & Yes (1)/No (0) \\
\hline 8 & Not lowering of environment and/or labor standards & Yes (1)/No (0) \\
\hline 9 & Subrogation clause & Yes (1)/No (0) \\
\hline \multirow[t]{2}{*}{10} & Non-derogation clause & Yes (1)/No (0) \\
\hline & Investment promotion & \\
\hline 11 & $\begin{array}{l}\text { Reference to specific promotion activities in text of agreement } \\
\text { Institutional Issues }\end{array}$ & Yes (1)/No (0) \\
\hline 12 & Mechanism for consultations between State parties & Yes (1)/No (0) \\
\hline
\end{tabular}

Note: List of investment facilitation provisions are shown in No.1-10 and investment promotion provisions in No.11-12. Source: UNCTAD (2020b). 


\section{Appendix B}

Table A3 shows the list of bilateral investment treaties (BITs) and treaties with investment provisions (TIPs) among ASEAN countries and RCEP- 6 countries. There are 57 BITs in force and 11 TIPs in force used in this study.

Table A3. List of bilateral investment treaty and treaties with investment provisions.

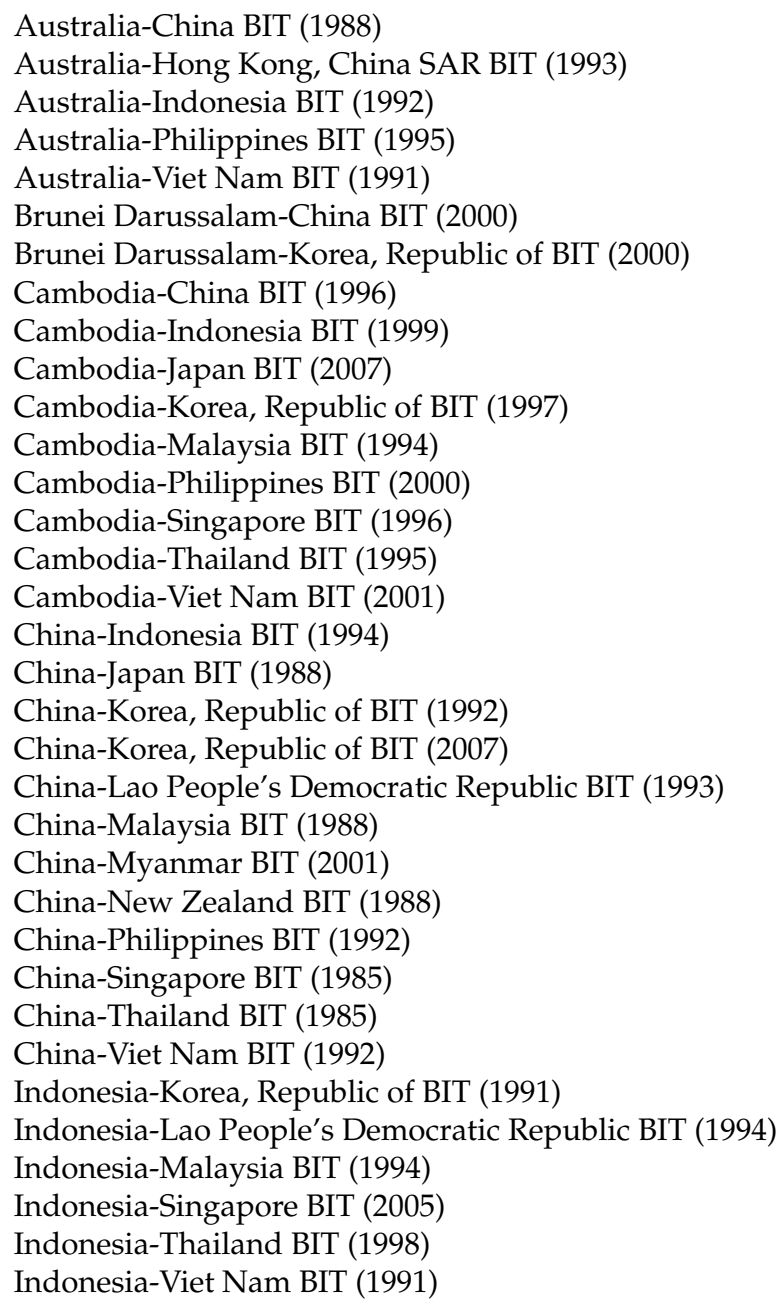

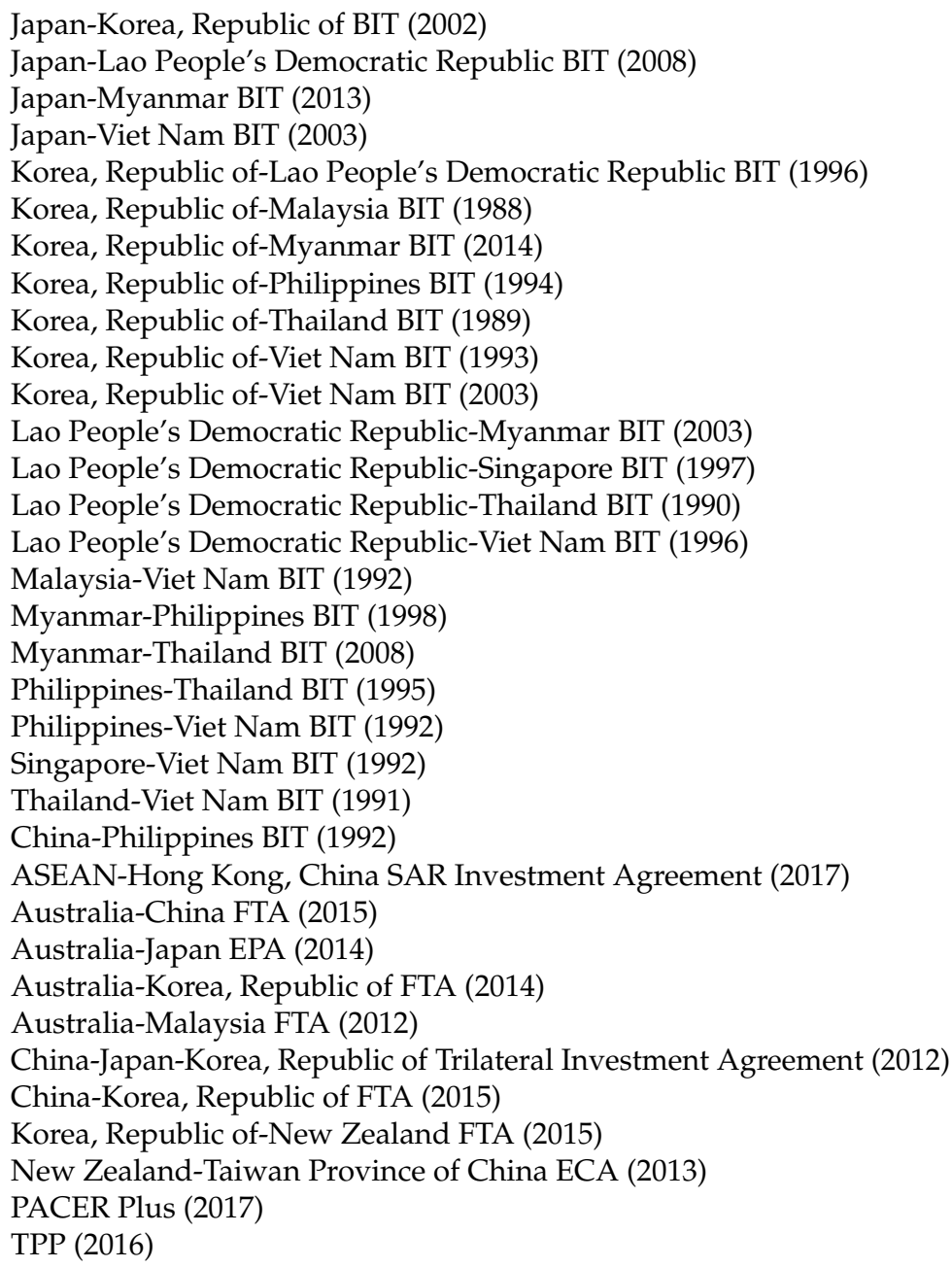

Source: UNCTAD (2020b).

\section{References}

Aisbett, Emma, Matthias Busse, and Peter Nunnenkamp. 2018. Bilateral Investment Treaties as Deterrents of Host-Country Discretion: The Impact of Investor-State Disputes on Foreign Direct Investment in Developing Countries. Review of World Economics 154: 119-55. [CrossRef]

Alschner, Wolfgang, Manfred Elsig, and Rodrigo Polanco. 2020. Introducing the Electronic Database of Investment Treaties (EDIT): The Genesis of a New Database and Its Use. World Trade Review, 1-22. [CrossRef]

Baldwin, Richard E., Rikard Forslid, and Jan I. Haaland. 1996. Investment Creation and Diversion in Europe. The World Economy 19: 635-59. [CrossRef]

Baldwin, Richard E., Rikard Forslid, Jan I. Haaland, and Alasdair Smith. 2010. 8-Investment Creation and Investment Diversion: Simulation Analysis of the Single Market Programme. In Dynamic Issues in Commercial Policy Analysis. Edited by Richard E. Baldwin and Joseph F. Francois. Cambridge: Cambridge University Press, pp. 228-68. [CrossRef]

Beebeejaun, Ambareen. 2018. The Role of International Investment Agreements in Attracting FDI to Developing Countries: An Assessment of Mauritius. International Journal of Law and Management 60: 150-71. [CrossRef]

Beck, Nathaniel, and Jonathan N. Katz. 1995. What to do (and not to do) with Time-Series Cross-Section Data. American Political Science Review 89: 634-47. [CrossRef]

Bengoa, Marta, Blanca Sanchez-Robles, and Yochnana Shachmurove. 2020. Do Trade and Investment Agreements Promote Foreign Direct Investment within Latin America? Evidence from a Structural Gravity Model. Mathematics 8: 1882. [CrossRef] 
Berger, Axel, Matthias Busse, Peter Nunnenkamp, and Martin Roy. 2013. Do Trade and Investment Agreements Lead to More FDI? Accounting for Key Provisions inside the Black Box. International Economics and Economic Policy 10: 247-75. [CrossRef]

Chaisse, Julien, and Christian Bellak. 2011. Do Bilateral Investment Treaties Promote Foreign Direct Investment? Preliminary Reflections on a New Methodology. Transnational Corporations Review 3: 3-10. [CrossRef]

Colen, Liesbeth, Damiaan Persyn, and Andrea Guariso. 2016. Bilateral Investment Treaties and FDI: Does the Sector Matter? World Development 83: 193-206. [CrossRef]

Dee, Philippa, and Jyothi Gali. 2005. 5-The Trade and Investment Effects of Prererential Trading Arrangements. In International Trade in East Asia. Edited by Takatoshi Ito and Andrew K. Rose. Chicago: University of Chicago Press, pp. 133-75.

Desbordes, Rodolphe, and Vincent Vicard. 2009. Foreign Direct Investment and Bilateral Investment Treaties: An International Political Perspective. Journal of Comparative Economics 37: 372-86. [CrossRef]

Dixon, Jay, and Paul Alexander Haslam. 2015. Does the Quality of Investment Protection Affect FDI Flows to Developing Countries? Evidence from Latin America. The World Economy 39: 1080-108. [CrossRef]

Driscoll, John C., and Aart C. Kraay. 1998. Consistent Covariance Matrix Estimation with Spatially Dependent Panel Data. Review of Economics and Statistics 80: 549-60. [CrossRef]

Egger, Peter, and Michael Pfaffermayr. 2004. The Impact of Bilateral Investment Treaties on Foreign Direct Investment. Journal of Comparative Economics 32: 788-804. [CrossRef]

Egger, Peter, and Valeria Merlo. 2007. The Impact of Bilateral Investment Treaties on FDI Dynamics. The World Economy 30: 1536-49. [CrossRef]

Egger, Peter, and Valeria Merlo. 2012. BITs Bite: An Anatomy of the Impact of Bilateral Investment Treaties on Multinational Firms. The Scandinavian Journal of Economics 114: 1240-66. [CrossRef]

Frenkel, Michael, and Benedikt Walter. 2018. Do Bilateral Investment Treaties Attract Foreign Direct Investment? The Role of International Dispute Settlement Provisions. The World Economy 42: 1316-42. [CrossRef]

Hoechle, Daniel. 2007. Robust Standard Errors for Panel Regressions with Cross-Sectional Dependence. Stata Journal 7: 281-312. [CrossRef].

International Trade Centre (ITC). 2020. Investment Map Database. Geneva: Switzerland. Available online: https://www. investmentmap.org/home (accessed on 15 November 2020).

Jacobs, Michael N., and Robert L. Ostergard. 2019. An Investigation of Variation in Bilateral Investment Treaties: Exploring Every BIT. Transnational Corporations Review 11: 24-37. [CrossRef]

Jung, Heon Joo, and Eun Mi Kim. 2019. International Treaties and Foreign Direct Investment: An Empirical Analysis of Effects of Bilateral Investment Treaties on South Korea's FDI. Journal of the Asia Pacific Economy 25: 402-17. [CrossRef]

Konan, Denise Eby, and Jeffrey S. Heinrich. 1997. Regional Integration and Investment Creation. Working Papers 199711. Honolulu: University of Hawaii at Manoa, Department of Economics.

Kreinin, Mordechai E., and Michael G. Plummer. 2008. Effects of Regional Integration on FDI: An Empirical Approach. Journal of Asian Economics 19: 447-54. [CrossRef]

Lakatos, Csilla, and Terrie Walmsley. 2012. Investment Creation and Diversion Effects of the ASEAN-China Free Trade Agreement. Economic Modelling 29: 766-79. [CrossRef]

Markusen, James R. 2002. Multinational Firms and the Theory of International Trade. Cambridge: MIT Press, pp. 127-52.

Medvedev, Denis. 2012. Beyond Trade: The Impact of Preferential Trade Agreements on FDI Inflows. World Development 40: 49-61. [CrossRef]

Neumayer, Eric, Peter Nunnenkamp, and Martin Roy. 2016. Are Stricter Investment Rules Contagious? Host Country Competition for Foreign Direct Investment through International Agreements. Review of World Economics 152: 177-213. [CrossRef]

Newey, Whiney K., and Kenneth D. West. 1987. A Simple, Positive Semi-Definite, Heteroskedasticity and Autocorrelation Consistent Covariance Matrix. Econometrica 55: 703-8. [CrossRef]

Nguyen, Anh T. N., Alfred A. Haug, P. Dorian Owen, and Murat Genç. 2020. What Drives Bilateral Foreign Direct Investment among Asian Economies? Economic Modelling 93: 125-41. [CrossRef]

Park, Innwon, and Soonchan Park. 2009. Reform Creating Regional Trade Agreements and Foreign Direct Investment: Applications for East Asia. Pacific Economic Review 13: 550-66. [CrossRef]

Parks, Richard W. 1967. Efficient Estimation of a System of Regression Equations when Disturbances are Both Serially and Contemporaneously Correlated. Journal of the American Statistical Association 62: 500-9. [CrossRef].

Tanaka, Kiyoyasu, and Shawn Arita. 2016. The Impact of Regional Investment Liberalization on Foreign Direct Investment: A Firm-Level Simulation Assessment. Japan and the World Economy 37-38: 17-26. [CrossRef]

The World Bank Group (World Bank). 2020. World Development Indicators Databank. Washington, USA. Available online: https: / / databank.worldbank.org/reports.aspx?source=world-development-indicators (accessed on 15 November 2020).

Tulayasathien, Soraphol, and Aurakanya Tejapaibul. 2017. Chapter 3-Investment Promotion and Liberalization in Selected ASEAN Countries. In Internationalization and Managing Networks in the Asia Pacific. Edited by Nipawan Thirawat. Bangkok: Chandos Publishing, pp. 29-51. [CrossRef]

United Nations Conference on Trade and Development (UNCTAD). 2015. Investment Policy Framework for Sustainable Development. New York: United Nations Publications. 
United Nations Conference on Trade and Development (UNCTAD). 2020a. World Investment Report 2020 International Production Beyond the Pandemic. New York: United Nations Publications.

United Nations Conference on Trade and Development (UNCTAD). 2020b. UNCTAD IIA Mapping Project. Available online: https:/ /investmentpolicy.unctad.org/international-investment-agreements/iia-mapping (accessed on 15 November 2020).

United Nations Conference on Trade and Development (UNCTAD). 2020c. The UNCTADStat. Geneva: Switzerland. Available online: https:/ / unctadstat.unctad.org/EN/Index.html (accessed on 15 November 2020).

Wang, Xiaoxiao. 2016. Analysis of the Effect of CEPA on FDI to Mainland China from Hong Kong. Modern Economy 7: 477-84. [CrossRef]

Xiao, Jun. 2011. The ASEAN-China Investment Agreement: A Regionalization of China's BITs. Frontiers of Law in China 6: 241-58. [CrossRef]

Zeng, Ka, and Yue Lu. 2016. Variation in Bilateral Investment Treaty Provisions and Foreign Direct Investment Flows to China, 1997-2011. International Interactions 42: 820-48. [CrossRef] 